UNIVERSIDADE DE SÃO PAULO

FACULDADE DE FILOSOFIA, CIÊNCIAS E LETRAS DE RIBEIRÃO PRETO

DEPARTAMENTO DE PSICOLOGIA E EDUCAÇÃO

PROGRAMA DE PÓS-GRADUAÇÃO EM PSICOLOGIA

\title{
Paternidade: a experiência de pais de meninos com Distrofia Muscular de Duchenne
}

\author{
Silvana Aparecida De Lucca
}

Dissertação apresentada à Faculdade de Filosofia, Ciências e Letras de Ribeirão Preto da USP, como parte das exigências para a obtenção do título de Mestre em Ciências, Área: Psicologia.

Orientadora: Profa. Dra. Eucia Beatriz Lopes Petean

Ribeirão Preto - SP 
Autorizo a reprodução e divulgação total ou parcial deste trabalho, por qualquer meio convencional ou eletrônico, para fins de estudo e pesquisa, desde que citada a fonte.

\section{FI CHA CATALOGRÁFI CA}

Lucca, Silvana Aparecida De

Paternidade: a experiência de pais de meninos com Distrofia Muscular de Duchenne. Ribeirão Preto, 2013.

126 p. : il. ; $30 \mathrm{~cm}$

Dissertação, apresentada à Faculdade de Filosofia, Ciências e Letras de Ribeirão Preto / USP - Dep. de Psicologia e Educação.

Área de concentração: Psicologia

Orientadora: Petean, Eucia Beatriz Lopes

1. Paternidade. 2. Distrofia Muscular de Duchenne. 3. Estratégias de enfrentamento. 4. Interações familiares. 5. Luto. 


\section{FOLHA DE APROVAÇÃO}

Silvana Aparecida De Lucca

Paternidade: a experiência de pais de meninos com Distrofia Muscular de Duchenne

Dissertação apresentada à Faculdade de Filosofia, Ciências e Letras de Ribeirão Preto da USP, como parte das exigências para a obtenção do título de Mestre em Ciências, Área: Psicologia.

Aprovado em:

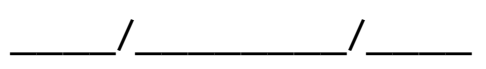

Banca Examinadora

Prof. Dr.

Instituição: Assinatura:

Prof. Dr.

Instituição: Assinatura:

Prof. Dr. Instituição: Assinatura: 

Dedico este trabalho

aos meus filhos muito amados, José Vitor e J orge Gustavo.

Ao J oão, que muito me incentivou com seu apoio e compreensão, me ajudando nesta trajetória de vida, repleta de percalços mas também de alegrias compartilhadas.

Aos meus pais queridos, Gelci e J oão Batista (in memorian) por seu exemplo e seu amor, que ainda sinto vivo e sempre presente em meu coração. 

À Prof. Eucia Beatriz Lopes Petean, pela competência, sensibilidade e paciência durante todo o desenvolvimento deste trabalho.

Aos Professores Manoel Antonio dos Santos e Ana Maria Pimenta pelas valiosas sugestões dadas durante o exame de qualificação.

À AADM que contribuiu de modo especial com informações acerca da doença e de participantes.

A FAPESP por viabilizar financeiramente este trabalho.

As minhas queridas Angela, Lúcia, Taciana, Aline, Isabela, Juliana Godoy, Juliana Leonardi, Marta Lúcia, Patrícia, Jacira, Alcione, Daniela pelo apoio, incentivo e amizade.

Em especial, aos pais que se disponibilizaram a participar, contando suas histórias de vida e de superação. 



\section{Resumo}

Lucca, S.A. de. Paternidade: a experiência de pais de meninos com Distrofia Muscular de Duchenne. 2013. 126 f. Dissertação (Mestrado)

- Faculdade de Filosofia Ciências e Letras de Ribeirão Preto, Universidade de São Paulo, Ribeirão Preto, 2013.

Em nossa cultura casar-se e ter filhos são etapas no processo de desenvolvimento do ser humano que têm amplo significado social e psicológico; e ser pai/mãe é uma etapa dentro do ciclo de vida que traz mudanças significativas, tanto para a família, como um todo, quanto para seus membros. Assim como a maternidade tem seus significados para a mulher, a paternidade também os tem e estes, para os homens, são influenciados pelas concepções, crenças e valores que têm acerca do papel paterno. A literatura aponta que a presença de uma doença crônica/deficiência do filho afeta a maneira como estes homens exercem a paternidade. Este trabalho teve como objetivo conhecer a vivência da paternidade em pais de filhos com diagnóstico de Distrofia Muscular de Duchenne (DMD) e as consequências da presença da doença nas interações familiares e sociais. Participaram oito pais cujos filhos possuem diagnóstico confirmado de DMD, com idade acima dos dez anos e residentes em Ribeirão Preto e cidades circunvizinhas. Foram realizadas entrevistas com a utilização de um roteiro semiestruturado e os dados foram analisados com base na análise temática de conteúdo. Os resultados mostram que a notícia da confirmação do diagnóstico de DMD desencadeou uma reação de choque, coexistindo com sentimentos de tristeza, impotência e desesperança. A negação foi a defesa psíquica mais utilizada por eles e a maioria dos pais considera a enfermidade do filho como missão enviada por Deus, desse modo diminuindo a dor e a angústia causadas pelo adoecimento. Os pais utilizaram-se de diversos recursos para enfrentar a doença dos seus filhos, desde a busca de informações sobre tratamento/cura da doença e a religião apareceu como 
um fator positivo que os ajudou a enfrentar as situações mais difíceis. Apresentam sobrecarga física e psíquica e, ainda, preocupação constante e tristeza em virtude da grande dependência de cuidados que o filho doente exige; além disso, o exercício da paternidade se mostrou mais participativo, sendo o relacionamento com o filho avaliado como de companheirismo. Os pais experimentam, desde a percepção dos sintomas da doença, inúmeras perdas que os expõem a grande sofrimento, diversos eventos estressores e deflagram o processo de luto antecipatório que é atualizado a cada perda funcional que acontece em decorrência da doença. A paternidade de um filho com deficiência foi percebida por eles como um fator que os fez sentirem-se "pais especiais", promovendo também amadurecimento e crescimento pessoais. Os pais atribuíram à paternidade o significado de missão a ser cumprida e este significado foi permeado pelo sistema de crenças e valores religiosos. O significado dado à "paternidade especial" influenciou positivamente na adaptação à doença, pois favoreceu a elaboração psíquica, mantendo-os motivados frente à adversidade. Conhecer e compreender como os pais vivenciam a paternidade na presença de uma doença crônica/deficiência é fundamental para que se estabeleçam programas de acompanhamento psicológico e assistência não somente para os pais, mas para toda a família, visando à promoção de apoio e estratégias de enfrentamento para uma melhor adaptação à enfermidade e à paternidade.

Palavras chave: Paternidade, Distrofia Muscular de Duchenne, Estratégias de enfrentamento, Interações familiares, Luto. 


\section{Abstract}

Lucca, S.A. de. Fatherhood: the experience of fathers of boys with Duchenne Muscular Dystrophy. 2013. 126 f. Master's thesis Faculdade de Filosofia Ciências e Letras de Ribeirão Preto, Universidade de São Paulo, Ribeirão Preto, 2013.

In our culture to marry and have children are steps in the process of human development that have broad social and psychological meaning and to become a father/mother is a stage in the life cycle that brings significant changes for both the family and its members. As well as motherhood having its meanings for the woman fatherhood also has them and this is influenced by the concepts, beliefs and values of the men concerning the paternal role. The literature indicates that the presence of a chronic illness/disability of the child affects how these men exercise fatherhood. This study aimed to understand the experience of fatherhood in fathers of boys diagnosed with Duchenne Muscular Dystrophy (DMD) and the consequences of the presence of the disease in the social and family interactions. Participants were eight fathers whose children, aged ten years and over, had been diagnosed with DMD, living in Ribeirão Preto and surrounding cities. Interviews were conducted using a semi-structured script and analyzed using thematic content analysis. The results show that the news of the confirmation of the DMD diagnosis triggered a reaction of shock, coexisting with feelings of sadness, helplessness and hopelessness. Denial was the psychic defense most used by them and the majority of the fathers considered the illness of the child a mission sent from God, thereby decreasing the pain and anguish caused by the illness. The fathers used a variety of resources to cope with the illnesses of their sons, from seeking information regarding treatment/cure for the disease to religion, which appeared as a positive factor that helped them cope with the most difficult situations. They presented physical and mental overload, as well as constant concern and sadness because of the great dependence 
on care of the sick son. The exercise of fatherhood was shown to be more participatory and the relationship with the child was evaluated as one of companionship. From the perception of the disease symptoms, the fathers experienced many losses that exposed them to great suffering, many stressful events and triggered the process of anticipatory mourning that was upgraded with every functional loss that occured as a result of the disease. They perceived fatherhood of a child with disabilities to be a factor that made them feel like "special parents" and also promoted maturation and personal growth. The fathers attributed the meaning of a mission to be fulfilled to the fatherhood and this meaning was permeated by a system of religious beliefs and values. The meaning given to "special fatherhood" positively influenced the adaptation to the disease, as it favored psychic elaboration, keeping them motivated in the face of adversity. To know and comprehend how fathers experience fatherhood in the presence of a chronic disease/disability is fundamental to be able to establish psychological counseling and care programs, not only for parents but for the entire family, aiming to promote support and coping strategies for better adaptation to the illness and to fatherhood.

Keywords: Fatherhood, Duchenne Muscular Dystrophy, Coping strategies, Family interactions, Mourning. 


\section{Sumário}

1 I NTRODUÇÃO....................................................................... 15

1.1 Distrofia Muscular de Duchenne e a família ......................... 33

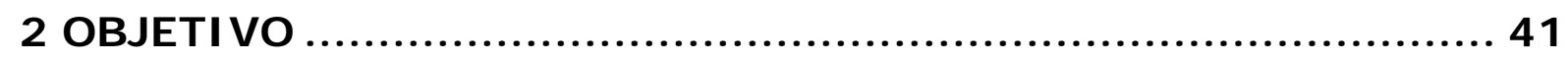

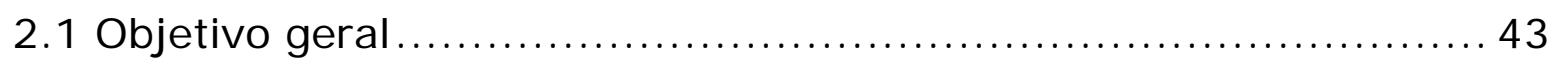

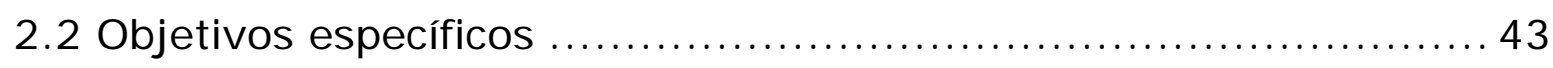

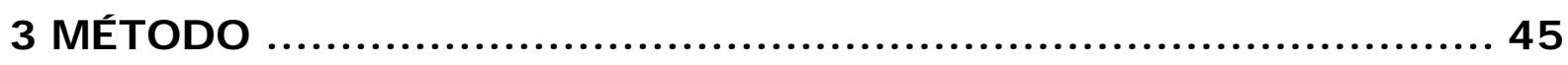

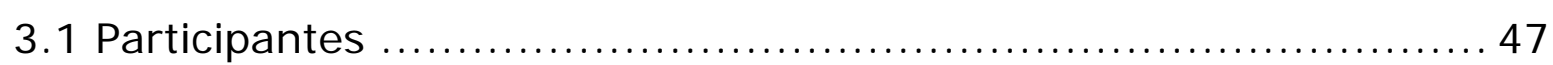

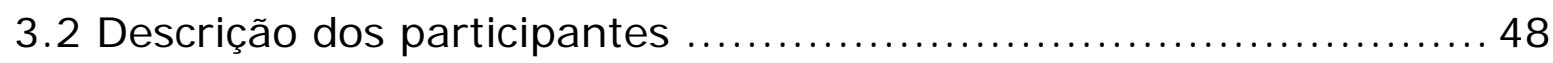

3.3 A entrevista: instrumento utilizado para a coleta de informações .. 49

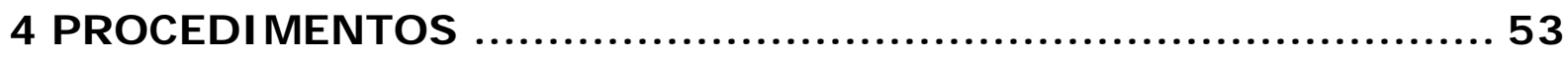

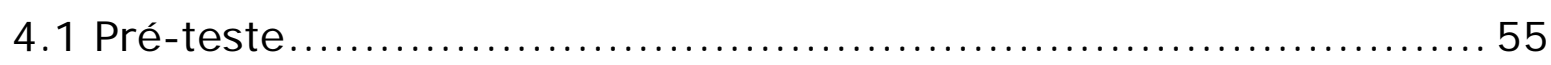

4.2 Procedimento para Coleta de Dados ............................ 55

4.3 Procedimento para análise ....................................... 55

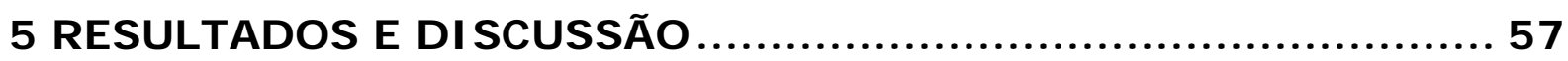

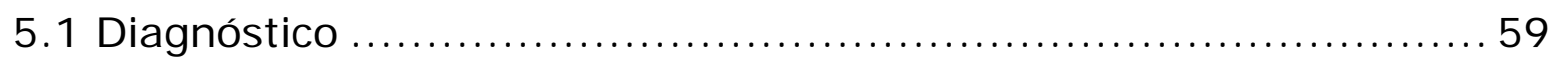

5.2 Significado atribuído à doença....................................... 68

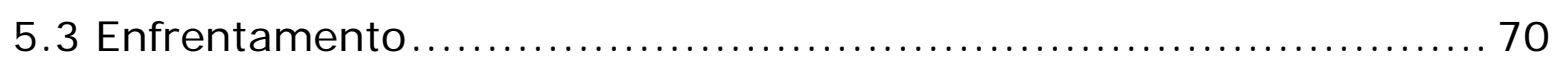

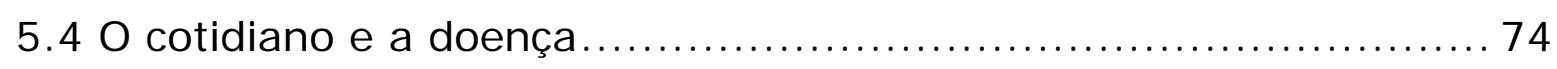

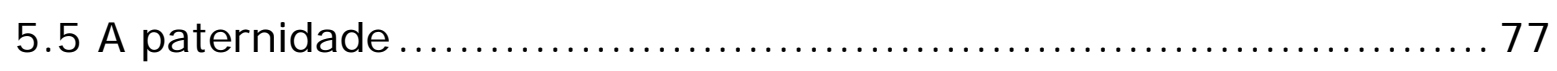

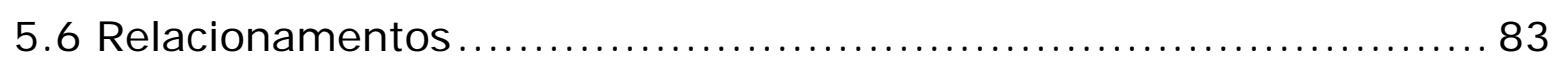

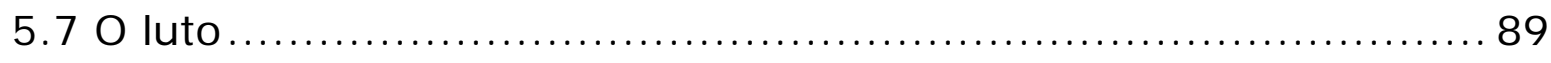

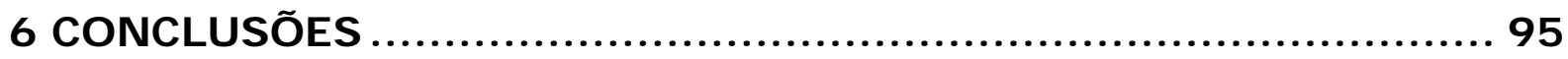

REFERÊNCI AS ................................................................ 103 
Anexo A - Procedimento de Reavaliação do roteiro semi-estruturado da entrevista e as modificações efetuadas. ............................. 117

Anexo B - Roteiro Final da Entrevista ................................. 121

Anexo C - Termo de Consentimento Livre e Esclarecido ................. 125 

Em nossa cultura casar-se e ter filhos são etapas no prcesso de desenvolvimento do ser humano que têm amplo significado social e psicológico e ser pai/mãe é uma etapa que traz mudanças significativas tanto para a família quanto para os seus membros. O nascimento de um filho, mesmo que esperado, requer uma alteração na dinâmica do relacionamento do familiar, que obriga seus membros a uma adaptação à nova realidade, alterando papéis, relações e os vínculos afetivos existentes (MINUCHIM, 1990; CLARK; MILES, 1999; CARTER; MCGOLDRICK, 2001; PETEAN, 2004; DESSEN; COSTA JUNIOR, 2005).

O exercício da paternidade é de suma importância para o ciclo de vida da família e também para o desenvolvimento do homem. São profundas as mudanças que a transição para a paternidade exige, de acordo com Bradt (2001). Para ele, o tornar-se pai é o momento mais desafiante do ciclo de vida familiar e individual.

Atualmente, com as mudanças no panorama social e a consequente necessidade de trabalho de ambos os cônjuges, essa dificuldade torna-se ainda maior. A criança recém-chegada demanda espaço na vida dos progenitores e em todas as dimensões da vida do casal. Tradicionalmente esperam-se da mãe os cuidados com o lar e a família, tendo seu papel como determinante no desenvolvimento físico-psíquico-social do filho. Os pais são vistos em nossa cultura com uma função periférica ao desenvolvimento da criança, com atributos de apoio extra para ajudar na educação dos filhos e como espectadores do processo.

Minuchim (1990) afirma que mesmo com as diferenças sóciohistórico-culturais, as famílias enfrentam uma série de tarefas desenvolvimentais que as impelem a novas adaptações, reestruturações e acomodações para manter a convivência entre seus membros e para que estes possam continuar o seu desenvolvimento como indivíduos e como sistema familiar.

Apesar de se reconhecer que tanto pais quanto mães são importantes no desenvolvimento dos filhos, até bem pouco tempo havia um número maior de estudos com mães sobre o desenvolvimento infantil 
e a maternidade. Dessen e Lewis (1998) afirmam haver uma predominância nos estudos feitos para esclarecer as inter-relações na díade mãe-filho, contrastando com o número menor de estudos sobre as outras díades do sistema, pai-filho, mãe-pai, que também são relevantes no processo desenvolvimental e que podem enriquecer o entendimento sobre desenvolvimento humano e sobre o sistema familiar. Estudos focando a díade pai/filho e o próprio papel paterno não são temas frequentes de pesquisas e, quando abordados nos estudos, são considerados com base no relato das mães. Entretanto, nos últimos cinco anos pode-se constatar um número crescente de estudos sobre a paternidade e sobre os homens.

Quanto à literatura acerca da transição para a paternidade, numa perspectiva sistêmica, Polônia et al. (2005) expõem que os recursos psicológicos e sociais dos pais são importantes fatores de desenvolvimento, funcionando como alavancas no processo evolutivo dos filhos e dos próprios pais, influenciando sobremaneira as interações familiares.

Todavia, para os estudos a respeito deste tema, é importante que a paternidade seja vista como uma atividade de perspectivas históricas e culturais (DESSEN; LEWIS, 1998). O modelo de homem-pai vigente em nossa cultura vem sendo construído socialmente baseado no modelo de autoridade e poder, colocando o pai como protetor moral, que é racional e tem controle sobre as emoções, como neutralizador das tensões familiares. A paternidade, neste sistema, visa cumprir uma etapa e tem o sentido de reafirmar a virilidade e esclarecer a identidade sexual do homem (AUN; ESTEVES DE VASCONCELLOS; COELHO, 2005).

I mbricados à noção de paternidade encontram-se ainda as questões de gênero e o estereótipo masculino. O padrão de virilidade do macho latino inclui características de um herói irrefutável: "nunca chora; tem que ser o melhor; competir sempre; ser forte; jamais se envolver afetivamente e nunca renunciar" (NOLASCO, 1995, p. 40).

Assim, o tornar-se pai é um processo que passa por vários momentos, da gestação ao exercício da paternidade. Dessen e Braz 
(2000), referindo-se ao momento de transição para a paternidade, em decorrência do nascimento de filhos, apontam para o pai como fator importante para o funcionamento da família, pois a adaptação a esta nova fase depende da complementaridade de papéis entre os genitores, tanto ao nível das interações como das relações familiares mais amplas, incluindo a divisão de tarefas domésticas.

Krob et al. (2009) verificaram que os pais vivenciam a gestação com sentimentos intensos de alegria, ansiedade e conflito, preocupações com a saúde da mãe e do bebê e também que experimentam sentimentos de exclusão no período pré e pós-natal, que têm expectativas acerca do papel paterno e que estas expectativas relacionam-se a serem pais participativos e presentes na vida dos filhos.

O trabalho de Genesoni e Talladini (2009) sobre a transição para a paternidade reflete os estudos publicados nesta área no período de 1989 a 2008, nos Estados Unidos e na Europa. Neste trabalho, revisaram a literatura que verificou a paternidade em fases diferentes: no período pré-natal, no parto e no pós-parto. Encontraram que há fortes evidências de que o envolvimento paterno é importante para o desenvolvimento da criança. Sobre os fatores intrapsíquicos, relacionais e aspectos sociais da transição para a paternidade, encontraram que importantes modificações ocorrem nos pais, como reelaboração da autoimagem, ocorrendo o desenvolvimento de um relacionamento triádico, mãe-pai-bebê e que este processo sofre influências do meio socioambiental. Em se tratando da autoimagem, o homem realiza mudanças no seu estilo de vida desde o período pré-natal e a principal dificuldade neste período parece relacionar-se a um decréscimo de sua independência; ele sente que perde o controle da situação por apresentar novas experiências e pode manifestar ansiedade, irritabilidade, frustração e uma percepção negativa de si mesmo. A participação do homem no trabalho de parto se mostrou como algo importante no aprendizado de como lidar com esta fase de transição. No processo de pós-parto, pode experimentar sentimentos ambíguos 
em relação ao bebê. De modo especial, o trabalho de parto foi vivenciado como uma experiência negativa; além disso, sua autoimagem pode ser afetada, se encontrar dificuldades para lidar com as demandas do novo papel e experimentar sentimentos de exclusão nas inter-relações. Além disso, socialmente mãe e bebê recebem mais atenção do grupo em que estão inseridos. No âmbito relacional, pelo fato de não ocorrerem mudanças físicas em seus corpos, os homens podem lutar psicologicamente contra a existência real desta criança, o que pode dificultar a vinculação com ela nos primeiros meses após o nascimento. No período pós-natal, a qualidade do relacionamento com sua parceira é gradualmente modificada, pois, a presença de um outro ser humano na relação, o bebê, vai transformando-a em uma relação triádica. Neste sentido, as mães, que são as principais cuidadoras dos bebês podem auxiliar sobremaneira no estabelecimento de uma boa relação pai-mãe-filho, facilitando o acesso do pai à criança. Dentre os elementos ambientais encontram-se principalmente as mudanças no estilo de vida. O homem percebe que pode perder seu status social, pois pode dedicar menos tempo ao trabalho e a outras atividades sociais; entretanto, um sentimento mais positivo em relação à paternidade parece ocorrer nos homens, que experimentam menos mudanças no trabalho e nas atividades sociais. Em suma, este processo de transição e de formação da identidade paterna envolve transformações que ocorrem simultaneamente na remodelação da autoimagem, na formação da relação triádica e na adaptação ao novo papel social.

Após o momento de transição para a paternidade, estabelecem-se os papéis dentro do sistema familiar que são inerentes ao contexto sóciohistórico-cultural. Mais especificamente na cultura brasileira, o papel paterno está mais relacionado com a provisão material da família. Silva e Piccinini (2007) revelam que os pais têm procurado participar de maneira mais próxima dos cuidados com os filhos, mas salientam que neste estudo os participantes tinham um nível de escolaridade elevado, revelando que estes 
achados não podem ser generalizados, mas, mesmo assim, isto reflete uma mudança nas expectativas sobre o papel paterno.

Em estudo sobre a paternidade e o desemprego, Souza e Benetti (2008) verificaram que o grau de envolvimento paterno é influenciado por fatores como escolaridade e capacidade financeira de manter a família.

Para avaliar mais recentemente esta noção da paternidade, foi realizado um estudo por Freitas et al. (2009) que conclui que a paternidade, no Brasil, é exercida predominantemente no campo das responsabilidades sociais, reproduzindo o papel tradicional de pai. Mas atesta também que vem ocorrendo a construção de uma dimensão afetiva da paternidade.

Moreira et al. (2010) descrevem a ascensão e o declínio do "pai patriarcal" na sociedade brasileira com o aporte da sociologia e da antropologia. As mudanças percebidas no papel paterno são vistas, desse modo, como reflexos de vários momentos sócio-políticos. No Brasil colônia, este papel era legitimado como o centro do núcleo familiar, o pai exercendo o papel de quem garante o provento, a lei e a distribuição dos afetos, a seguridade social.

De acordo com Moreira et al. (2010) o declínio deste papel inicia-se na época da abolição da escravatura e na ascendência das classes burguesa e média, com a emergência de outro tipo de cidadão que, mais acultuado pelo urbanismo e modernidade, busca se libertar da égide da tirania patriarcal. Passaram a ser referenciais os ideais republicanos, e com isto a contestação da autoridade dos avós e figuras de poder autoritário. A figura materna ganha projeção no cenário familiar, com a emancipação da mulher, sua inserção no mercado de trabalho e a busca pela igualdade de direitos.

A decadência do pai patriarcal, a emergência do feminismo e uma série de eventos sociopolíticos culminam no desempoderamento do pai no núcleo familiar e na busca de um novo papel paterno no cenário sociocultural e no núcleo familiar. (MOREIRA et al., 2010; NOLASCO, 1995). 
Para Moreira et al. (2010), sintetizando esta mudança, a antiga visão do pai patriarcal aproximou o papel paterno de outras marcas importantes para a vida familiar:

\begin{abstract}
“[...] o afeto, a compreensão da autoridade não como um regime de poderes, mas enquanto função prenhe de cuidados. Isto talvez seja tão insubstituível para o moderno processo de construção da personalidade na ausência do pai, quanto ligado ao desempenho da liberdade do indivíduo contemporâneo, sempre mais conflitivo e carente da socialização adequada." (p. 38)
\end{abstract}

Há referência, ainda, ao fato de que questões relativas à compreensão de como exercer o papel paterno são acrescidas de problemas "quanto à comunicação, definição de papéis, problemas de autoridade, divisão de tarefas, tomada de decisões, entre outras dificuldades". (Ceverny; Chaves, 2010). Estas autoras fazem uma distinção entre a "paternidade tradicional" e a "paternidade contemporânea", sendo a primeira associada ao papel principal de provedor e centro de decisão da família nas esferas morais e econômicas e a segunda referente ao processo de construção. Na atualidade, o modelo tradicional não contempla as necessidades dessa nova família em que tanto pai quanto mãe possuem ocupações e carreiras próprias e buscam a própria realização.

A paternidade define-se na relação pai-mãe e filho, de acordo com Ceverny e Chaves (2010). Tanto a paternidade quanto a maternidade passaram por uma evolução, mas estão longe de concluir o processo.

A ciência também tem se mostrado sensível ao estudo da paternidade e dos homens. Watts (2010) refere que há um avanço na comunidade de psicologia para o estudo do homem e do seu desenvolvimento e em seu trabalho descreve questões acerca do masculino, como forças sociais do passado e do presente, o colonialismo e a hegemonia da masculinidade e suas repercussões sobre o homem e seu papel na sociedade. Conclui que os métodos de pesquisa nesta área carecem de respeitar a "voz do homem" em toda sua complexidade, 
levando em consideração elementos históricos e ecológicos do comportamento masculino, com empatia, respeito e preocupação com a diversidade. Ou seja, considerando o contexto e diferenças de nacionalidade, orientação sexual, raça, classe social e cultura.

Em pesquisa realizada no Brasil acerca da transição para a paternidade com homens jovens, Brasileiro et al. (2010) encontraram algumas noções importantes que vêm sendo acrescidas de significado da paternidade. Para estes autores, ficou evidente a noção da "complementaridade na divisão de papéis e tarefas no contexto familiar", ou seja, a ambos, pai e mãe, cumpre atender às necessidades dos filhos. A figura de pai/cuidador se revela também neste estudo; este cuidado inclui uma grande afetividade em relação ao filho e à mãe.

Teykal (2007), estudando sobre os aspectos identitários da paternidade, enfatiza que o tornar-se pai envolve duas dimensões da identidade do indivíduo: a física, com a participação do pai na geração do filho; e a moral, que exige dele os recursos para sustentar e educar os filhos.

Demonstrando a preocupação em contextualizar o estudo e explicitar suas limitações quanto à regionalidade e cultura, Lemay et al. (2010) conduziram uma pesquisa qualitativa acerca do significado da paternidade para homens jovens. Esta revelou que tornar-se pai mostrouse um poderoso agente motivador para a promoção de mudanças no homem. Eles almejam, nesta fase, melhorar a si mesmos seja por meio da educação, de melhores empregos ou pelo próprio estilo de vida. Atingindo estes objetivos, tendem a aumentar o engajamento durante a gravidez e facilitar o relacionamento positivo entre eles e os filhos após o nascimento. Inversamente, percebeu-se que o fato de não atingirem as metas almejadas, tanto por experiências negativas com os próprios pais como pela inabilidade em manter financeiramente a família, contribui para diminuir a autoestima e autoeficácia dos homens jovens, interferindo negativamente no envolvimento com o filho ao longo do tempo. É sabido que durante a gravidez e no pós-natal a atenção volta-se prioritariamente para a mãe e a criança recém-chegada Os autores sugerem programas de 
intervenção nesta fase para que esses pais recebam modelos mais adequados para desenvolver melhores competências paternais, e de auxílio para a obtenção de uma situação econômica mais estável como facilitadores na transição para a paternidade. Aqui também se pode perceber que a questão do homem como bom provedor interfere na função parental, tal como no estudo brasileiro.

Manfroi et al. (2011) destacam que o pai tem um papel mais do que periférico no processo de desenvolvimento infantil, referindo-se a dois níveis de participação paterna: direta e indireta. Indiretamente sua participação garante a harmonização das relações familiares, contribuindo para um bom envolvimento entre mãe e filho e, diretamente, com a participação ativa nas tarefas domésticas, colabora com seu exemplo para a aquisição não só de seus valores como, também, do sentimento de cooperação.

No entanto, pode haver elementos complicadores no que concerne ao exercício do papel paterno. Pais de pessoas com doenças crônicas, deficiências causadas por acidentes ou por síndromes e outras condições não predizíveis têm sua vivência do papel paterno acrescida de dificuldades, o que exige deles novas adaptações.

Os pais de crianças deficientes corroboram com a noção de papel provedor paterno e demonstram que o papel do pai é percebido como essencialmente de provedor e o cuidado da criança fica a cargo da mãe. Portanto, para os pais, o cuidado com o filho assim como as tarefas domésticas, ficam em segundo plano (NUNES; SILVA; AIELO, 2008).

Silva e Dessen (2003) referem que os pais de crianças com síndrome de Down tendem a apresentar comportamentos de comunicação menos positivos e ainda taxas significativamente mais altas de reciprocidade negativa, quando comparados com pais de crianças com desenvolvimento normal. Entretanto, estes dados ainda não são conclusivos (SILVA; DESSEN, 2003).

O estresse parental é especialmente verdadeiro diante da ocorrência de um inesperado problema de saúde de um filho, como no caso das doenças crônicas ou com algum tipo de deficiência. Estes eventos 
impredizíveis do desenvolvimento imputam ao sistema familiar vivenciar medos, frustrações de desejos e expectativas depositadas nesta criança, muitas vezes obrigando os pais a se despojarem de planos e sonhos sobre o próprio futuro. Há uma ambivalência de sentimentos em relação ao membro que adoeceu que pode predispor a uma intimidade excessiva, ou a uma superproteção, bem como a um afastamento do doente, em virtude da expectativa antecipada da perda (ROLLAND, 1998; CARTER; MCGOLDRICK, 2001).

As conseqüências de uma doença crônica na vida familiar vão depender do seu curso, ou progressão, do nível de incapacitação do doente, do risco de morte; porém, a despeito destas características, a doença é vivenciada como uma situação iminente de perda, que desperta fantasias e angústias frente ao temor da degeneração física e da morte. Sua ocorrência se constitui numa situação adversa ao desenvolvimento e requer estratégias para que o desenvolvimento humano seja menos prejudicado (ROLLAND, 2001; DESSEN; COSTA JUNIOR, 2005).

São muitos os sentimentos que acompanham a notícia da doença e as preocupações oriundas desta nova condição, conforme os estudos descritos abaixo.

Os resultados de um estudo realizado por Clark e Miles (1999) indicam que os pais experimentam reações emocionais ambivalentes em decorrência do nascimento de um filho diagnosticado com uma doença cardíaca congênita. Os pais relatam a alegria experimentada com o nascimento da criança e por tornar-se um pai, juntamente com sentimentos de tristeza e perda associados com a doença do bebê. Além disso, informaram a dificuldade de manterem-se unidos à família, ao tratar dos medos despertados pela vulnerabilidade e risco potencial de morte da criança. Os pais, nesse estudo, revelaram também a dificuldade em manter o controle diante da doença, bem como o esforço necessário para permanecer forte para outros, escondendo emoções intensas.

Estudos sobre o impacto causado pela notícia de que um filho apresenta uma deficiência seja por malformação ou anomalia 
(BRUNHARA; PETEAN, 1999; PETEAN, 2004), revelam que os pais, mais frequentemente, apresentam uma reação de choque, sendo que esta reação não se repete ao longo do tempo e do processo de adaptação à doença crônica e/ou deficiência. A revolta ou raiva foi outra reação relatada pelos pais, que se sentem injustiçados com o aparecimento da doença em um membro de sua família. Esta raiva muitas vezes se volta contra os profissionais que cuidam da criança ou contra a própria família. Profundo pesar e tristeza, também são informados pelos participantes dos estudos e aparecem em decorrência da perda do "bebê esperado". As mães ainda apresentaram reações de conformismo, aceitação e resignação, mais relacionadas a valores religiosos, ao passo que os pais não os relataram como reação inicial. Os pais ainda relataram desejos de morte, tanto de si mesmos como do filho, como forma de lidar com a intensa angústia e desespero resultantes do impacto provocado pela notícia.

Sentimentos de vergonha, culpa, desesperança, tristeza, raiva por parte de familiares de crianças com doenças crônicas ou diversos tipos de deficiências têm sido relatados. Além disso, os familiares ficam expostos a um nível de estresse elevado, em virtude dos cuidados especiais que elas necessitam. Nos pais destas crianças persiste uma tristeza crônica ao longo da vida, mesmo naqueles que têm se adaptado melhor à nova situação (REGEN et Col, 1993; PETEAN, 2004).

Os familiares se deparam com preocupações e situações bastante relevantes a respeito do desenvolvimento da criança doente. Em estudo realizado num grupo de mães de crianças com deficiência, por Regen e colaboradores (1993), as principais questões versaram sobre a saúde da criança, a capacidade da família quanto a manter os tratamentos necessários, seja com recursos econômicos ou internos, as mudanças ocorridas nas interações familiares, a solidão no enfrentamento da doença, a rede de apoio familiar, a aceitação da família e sociedade, a perda da capacidade de trabalho, do cuidador e da criança no futuro. Estas crianças também se inserem em vários atendimentos necessários 
para o tratamento/adaptação à doença, suas implicações para o doente e a família além de sua inserção social. Miller et al. (2011), procurando compreender as inter-relações entre pessoas com doenças crônicas, seus familiares e os profissionais que as atendem, encontraram que um padrão de serviços continuados e com profissionais interconectados tem se mostrado como um auxiliar na promoção de um bem-estar físico e subjetivo, no engajamento ao tratamento e no enfrentamento da doença. Dúvidas acerca do futuro da criança são muitas e vão desde a escolarização, como e o que ela conseguirá desempenhar quando adulta, quem cuidará dela no caso de falecimento ou impossibilidade dos pais (REGEN et Col, 1993).

As mudanças exigidas pela presença de uma criança com doença crônica e/ou deficiência são muitas e requerem reestruturação familiar, tempo, novas atitudes, valores e estilo de vida. Cuidados metódicos e constantes, medicamentos, tratamentos e dietas especiais demandam capacidade de adaptação de todos os membros da família, sobretudo da mãe, a quem geralmente é delegada a responsabilidade pelos cuidados médicos. Contudo, o marido e os outros filhos do casal sofrerão conjuntamente por esta sobrecarga materna, ressentindo-se pela falta de atenção e pela modificação nos vínculos afetivos, sendo que cada membro reagirá de maneira distinta gerando tensões constantes no seio da família (BUSCAGLIA, 1993; PETEAN, 2004).

Rolland (2001) propõe que para compreender como uma doença crônica pode causar a desestrutura do sistema familiar é necessário que se atente para a complexidade dos seus desdobramentos em um contexto desenvolvimental, ou seja, no entrelaçamento entre a doença e os ciclos de vida do indivíduo e da família. De acordo com ele, é preciso conhecer as características da doença, o tipo de início (agudo/gradual), o seu curso (progressiva/constante/reincidente), o nível de incapacitação do indivíduo, e as fases temporais da doença (crise, crônica, terminal). Outra questão de grande importância neste modelo é o histórico de como a família lida com a doença, a crise e a perda, ou seja, como o sistema familiar se 
organiza em resposta a estressores passados e presentes. Além disso, importam o estilo e as fases familiares. O modelo proposto por CombrickGraham $^{1}$ apud Rolland (2001) mostra um sistema familiar em que cada indivíduo passará por três períodos de oscilação durante a vida: a própria infância e adolescência, os mesmos períodos para seus filhos e seus netos. Em cada um desses períodos predominam estilos familiares que vão cumprir o papel de aproximação na família em torno de tarefas de construção/ manutenção (movimento centrípeto) ou de movimentos de afastamento familiar (movimento centrífugo). Estes movimentos se referem tanto às fases em que há maior necessidade de interação com o ambiente quanto às fases que exigem a acomodação diante da troca de papéis dos membros da família.

Em geral, a doença crônica, tal qual a chegada de um novo membro na família (um bebê), exerce uma força centrípeta sobre o sistema familiar, que a impulsiona a um prolongado período em que as energias se voltam para dentro do sistema e acionam na família o processo centrípeto de socialização com a enfermidade, os sintomas, a perda de função, a exigência de mudanças relacionadas à nova doença, nos papéis práticos e afetivos, e o medo da perda através da morte; tudo isso serve para que a família crie um novo foco interno. (ROLLAND, 2001). Apesar disso, nem sempre ocorre desta maneira e os sistemas familiares podem responder de forma diversa a este novo estressor.

Sobre o impacto da doença crônica e o relacionamento do casal, Regen et al. (1993) relatam que esta doença pode tornar-se um fator desencadeante tanto de uma relação conjugal mais fortalecida, quanto de um estopim para a desunião, e neste caso a criança figura como bode expiatório. O pai, muitas vezes, sente-se excluído da relação e esta situação leva, via de regra, a um isolamento, um fechamento em si mesmo. Assim, compromete-se a troca afetiva na díade marido/mulher e cada qual fica só, com seus próprios sentimentos. Outras vezes, os pais

${ }^{1}$ Combrinck-Graham, L. (1985). A developmental model for family systems. Family Process 24:139150. 
procuram ajudar na divisão de tarefas domésticas e, dependendo dos valores culturais atribuídos ao seu papel, isto pode obrigá-los a uma significativa revisão de seus valores e crenças em relação à paternidade.

Os resultados de uma pesquisa que incluía tanto os pais de crianças com doenças crônicas, como os de crianças que apresentavam outras "injúrias não intencionais" (acidentais) mostraram que os primeiros ficaram mais expostos a desenvolver a síndrome de estresse póstraumático do que o outro grupo (RIBI et al., 2007).

A ocorrência da doença crônica ou deficiência numa família também faz com que a família se depare com a perspectiva da morte. Não apenas da morte física de um de seus membros, mas de todas as mortes subjetivas com as quais terão que lidar, ou seja, a morte do filho esperado, das expectativas, do desenvolvimento normal e até mesmo o perigo iminente da morte. A família tem que entrar em contato com o prognóstico da doença, muitas vezes carregado de desesperança e desinformação. Kübler-Ross (1995) descreve cinco estágios pelos quais as pessoas passam, ao lidar com qualquer forma de perda pessoal, sendo que a principal é a perspectiva da morte. A autora distinguiu um "padrão" de reações usuais frente à morte, que acontecem em estágios, mas não de forma única e linear. São eles: negação e isolamento, raiva, barganha, depressão e, finalmente, aceitação. Essas reações podem se referir não só à morte, mas também à perda de um objeto amado e podem-se verificar estes estágios nos estudos recentes com pais de crianças com deficiência. (PETEAN, 2005).

A família é levada à incerteza quanto às possibilidades tanto da cura como da perda antecipada do filho. Cada sintoma manifesto pela criança traz apreensão e sentimentos ameaçadores para a família. Estudos sobre o câncer demonstram que, mesmo 20 anos após o tratamento de um câncer, um sintoma vago pode reavivar os temores da família de uma recaída e morte. Sendo assim, a doença crônica faz a família experimentar, durante o tratamento, períodos estáveis ou de poucas manifestações, alternados com períodos de exacerbação, de modo que as 
questões relacionadas com a perda antecipada vão e vêm no cotidiano da família. Esta sofre com as exigências advindas tanto da frequência da transição entre as crises e os períodos calmos, quanto da incerteza a respeito de quando uma recaída fatal pode ocorrer. A doença, em seu aspecto regressivo, traz uma forte preocupação com manifestações corporais tanto na família quanto no doente. Quando a morte demora a acontecer, tem-se que aprender a reinvestir na vida, cuidar de si, pensar e aceitar a morte, senão o familiar também morre ao cuidar do doente. $\grave{E}$ frequente o aparecimento de doença grave no cuidador; e a família pode, também, enfrentar o processo de luto antecipatório (ROLLAND, 1998; KOVACS, 2002).

O processo vivido pelo paciente e sua família entre o período de diagnóstico, evolução da doença, progressiva ameaça de perda e a morte propriamente dita denomina-se luto antecipatório (RANDO, 2000).

O luto tem início a partir do momento em que é recebido o diagnóstico de uma doença fatal ou potencialmente fatal, complementado pelas perdas, concretas ou simbólicas, inerentes a esse diagnóstico e pelos efeitos que ele trará para a pessoa e sua família (FONSECA, 2004). As perdas se configuram em vários tipos, desde as relacionadas à segurança, a funções físicas e imagem corporal, força e poder, independência, autoestima, respeito dos demais e perspectiva de futuro.

Nesta perspectiva e tendo início com o diagnóstico da doença, instala-se o processo de luto antecipatório, descrito por Fonseca (2004) como sendo um fenômeno adaptativo que exige, tanto do paciente como dos familiares, a preparação cognitiva e emocional para o acontecimento próximo ou iminente, que é a morte. Isso causa um desequilíbrio, tanto no sistema familiar, como em cada pessoa individualmente.

“A antecipação da perda devido a uma doença física pode ser tão perturbadora e dolorosa para as famílias quanto a morte efetiva de um de seus membros" (ROLLAND, 1998). Este mesmo autor afirma que a perda antecipada acaba afetando não só o doente, mas todas as pessoas ao seu entorno, pois as faz entrar em contato com a própria morte. 
Esta experiência alicia uma gama de respostas emocionais como ansiedade de separação, solidão existencial, tristeza, desapontamento, raiva, ressentimento, culpa, exaustão e desespero. Nas famílias com membros acometidos por doenças crônicas, quando a perda pode ocorrer a longo prazo, vê-se a emergência de fenômenos como a superproteção e a hipervigilância, forçando a família a um processo de adaptação constante (ROLLAND, 1998).

Influirão neste processo especialmente os valores e significados atribuídos à incapacitação e à morte. No caso de doenças com curso progressivo, as famílias enfrentam o sofrimento antecipado face a cada marco da sua evolução e cada pequeno sinal de involução implica reviver os temores sobre a incapacidade e a morte (ROLLAND, 1998).

Kovacs (2008) salienta que a vivência de processos longos de morte, causados por doenças crônicas, degenerativas ou de curso lento, expõe todos os envolvidos a um processo também longo de luto, sujeitando-os a um desgaste físico e psíquico. Os cuidadores sofrem com a perda da pessoa que conheciam, havendo uma complicação no processo do luto. Sentimentos ambivalentes são vivenciados como "a tristeza pela perda e raiva pelo abandono, o desejo da morte para alívio do sofrimento, que pode provocar culpa, podendo ser este um fator de risco para o luto complicado" (KOVACS, 2008).

No entanto, além das perdas reais, a família, de modo especial, os pais, ainda tem que lidar com a perda do filho idealizado. O pai e a mãe têm dificuldade de encontrar, na criança real e acometida pela doença, vestígios ou marcas que se ajustem às representações do que eles desejam que seja o filho, de acordo com os seus ideais. Goes (2006), que estudou os pais e o nascimento de um filho com síndrome de Down, reportando-se a um referencial psicanalítico, diz que ocorre, então, uma "ruptura narcisística que se opera nos pais e faz com que eles tropecem em sérias dificuldades para encontrar, nessa criança, traços que se ajustem a esse ideal que haviam previamente estabelecido". Existe para estes pais a impossibilidade de o filho real aproximar-se do ideal em 
função da deficiência, o que dificulta o processo de identificação, provocando a perda do objeto idealizado. Essa perda se caracteriza como a perda de um ideal, ou seja, de um objeto que não chegou a constituir-se na realidade. Esse filho ideal, que contém o sujeito-bebê de cada um dos pais, retorna ao Ego de cada um deles e fará instalar-se uma estrutura de perda constantemente ativada, requerendo a vinda do filho saudável. Trata-se, dentro da visão psicanalítica, de uma ferida narcísica que permanecerá demandando a reparação.

O pai, como parte integrante do sistema familiar, estará exposto a esta vivência que lhe imputará a elaboração não só das perdas, como de novas adaptações, novas crenças e valores.

Muitas vezes, portanto, é necessária uma revisão no papel paterno, para que social e psicologicamente se possa construir uma visão mais humanizada de pai. É preciso privilegiar o afeto na relação com o filho, como parte de um projeto amoroso entre ambos, pois, antes de ser pai, existe um ser humano que sente e que coloca afeto nas relações (AUN; ESTEVES DE VASCONCELLOS; COELHO, 2005).

Atualmente, os estudos acerca da paternidade e do papel paterno têm crescido. Hennigen e Guareschi (2002) enfocaram a paternidade como uma construção social, por meio de uma propaganda de televisão, demonstrando também a influência da mídia e da cultura na construção identitária. Gomes e Resende (2004) estudaram sobre a paternidade nos dias atuais, enfocando as mudanças nos papéis sociais, a inclusão da mulher no mercado de trabalho e as transformações que ela vem apresentando. Balancho (2004) estudou a paternidade e as mudanças intergeracionais. Silva e Piccinini (2007) estudaram os sentimentos e o envolvimento paterno durante a gestação e no período pós-natal. As autoras Staudt e Wagner (2008) procuraram compreender a paternidade por meio de um referencial sistêmico, entendendo que esta é fruto de inter-relações nos contextos micro e macro sistêmicos. Gontijo et al. (2011) estudaram os significados atribuídos por pais adolescentes à paternidade na adolescência. Citando-se apenas alguns trabalhos sobre o 
tema, no Brasil, em uma pesquisa no portal de periódicos da Capes, encontram-se hoje vários autores e títulos com o descritor paternidade (CAPES, 2012).

No entanto, Cunniff (2012) atesta que ainda são poucos os estudos que versam sobre ajustamento dos pais na presença de uma doença crônica, especialmente na DMD. Conclui seu estudo acerca do ajustamento psicossocial de pais de pessoas acometidas pela doença, dizendo que os resultados encontrados enfatizaram a necessidade de intervenções biopsicossociais, reconhecendo o impacto que esta condição exerce sobre o papel e o envolvimento paternos. Salienta a necessidade de os profissionais compreenderem as implicações emocionais e os problemas com os quais estes pais se defrontam para que possam ajudálos no enfrentamento da doença

\subsection{Distrofia Muscular de Duchenne e a família}

A Distrofia Muscular de Duchenne (DMD) é uma doença crônica e degenerativa que acomete crianças do sexo masculino e se manifesta, em idade precoce, na época pré-escolar. A DMD é uma forma primária de distrofia muscular, um distúrbio geneticamente determinado, na qual o gene afetado é recessivo e ligado ao cromossomo $X$, e disto resulta que atinge apenas homens, pois nas mulheres, o outro cromossomo $X$ compensa a anomalia do outro cromossomo anômalo. Sendo assim, as mulheres podem ser portadoras do gene e transmiti-lo aos seus descendentes; entretanto, nelas não há manifestação do quadro clínico. Contudo, pode haver casos de DMD que são decorrentes de novas mutações genéticas. O gene afetado causa problemas na codificação da distrofina, proteína responsável pela manutenção das células musculares. É a forma mais comum de distrofia, com incidência aproximada de um em 3.500 meninos (BUSHBY; CONNOR, 2011). 
Nas pessoas com DMD ocorrem inúmeras perdas funcionais durante o seu processo de desenvolvimento. Essas perdas são decorrentes do dano causado às células musculares, levando a um declínio progressivo da capacidade de execução de tarefas corriqueiras como andar curtas distâncias e subir escadas. A fraqueza muscular progride e, no geral, os meninos perdem a capacidade de deambulação no início da segunda década de vida, ficando confinados a cadeiras de roda. Frequentemente ocorre o óbito com cerca de 20 anos de idade, em decorrência de complicações cardiorrespiratórias, pois a musculatura destes sistemas também é afetada. Ou seja, os meninos nascem saudáveis, avançam no desenvolvimento como todas as outras crianças, começam a trocar passos geralmente na idade esperada e, no entanto, situações corriqueiras da infância, como correr, subir escadas e levantar-se do chão denunciam que há algo diferente. Os pais percebem as diferenças de seus filhos em comparação a outras crianças e, então, inicia-se nesta altura a busca pelo diagnóstico e tratamento. Como referido, há uma involução sistemática, que atualmente só pode ser minimizada pela fisioterapia passiva, que cumpre o papel de retardar as perdas, sendo a causa mais comum de morte a insuficiência cardíaca por cardiomiopatia associada. A DMD tem os seguintes estágios: diagnóstico baseado em sinais de fraqueza muscular, dificuldades transitórias com a caminhada e posterior perda da capacidade de deambulação e, no estágio adulto, há a deterioração da musculatura do cardiorrespiratório (LEVY, 1989; SALTER; 2001) (LEVY, 1989; SALTER; 2001). Encontram-se também relacionados a esta patologia alterações eletrofisiológicas na retina e alterações visuais (BARBONI, 2012), além de problemas relativos à capacidade intelectual e competências sociais, em especial após a perda da deambulação (ZACHI et al., 2012).

A DMD, em geral, inicia a manifestação dos sintomas em torno dos 4 anos de idade, quando a criança apresenta atraso ou problemas no desenvolvimento motor. E a progressão da doença se dá de modo previsível, com a perda de diferentes capacidades como levantar-se do 
chão, subir escadas, levantar-se de uma cadeira, andar 10 metros e realizar a autoalimentação. (BUSHBY; CONNOR, 2011) (BUSHBY; CONNOR, 2011)

Atualmente, o avanço tecnológico tem prolongado a vida de pessoas com doenças crônicas severas e, como os cuidados geralmente ficam a cargo de familiares, esta condição tem levado a um aumento de estresse familiar, contribuído com um decréscimo na saúde do cuidador e aumentado a sobrecarga emocional e financeira. A forma como as famílias lidam com a doença é bastante particular, sendo que umas parecem se adaptar a este contexto melhor que outras. O estudo de Chen e Clark (2007) procurou explorar as relações existentes entre fatores relativos à criança com DMD - como o nível de incapacidade e idade no diagnóstico com fatores relacionados à família - como renda familiar, suporte familiar e a persistência vista como habilidade funcional da família. Persistência tem sido definida como uma força interna e durável na unidade familiar e se caracteriza por um senso de controle sobre eventos e situações, de modo a produzir mudanças positivas e eficientes, além de lidar com as situações de stress de maneira mais ativa. O resultado do estudo, entre outras informações relevantes, mostra que os familiares de crianças com DMD relatam condições mais precárias de saúde como ansiedade, depressão e dores, que a população em geral. O escore apurado sobre a persistência familiar mantém-se mais baixo nas famílias com portadores de DMD do que em famílias que apresentam indivíduos com asma, condições cardíacas ou diabetes, sugerindo a necessidade de mais estudos a respeito para que se encontrem meios de ajudar as famílias a manter e melhorar as condições internas de enfrentamento.

Para Daoud et al. (2004) os familiares (pais e mães) de pessoas com DMD têm maior probabilidade de apresentar episódios depressivos mais intensos. Estes referiram sentir mais angústia, desesperança, inquietude ou nervosismo, com sentimentos de menor valia que o grupocontrole. Os autores associam que estas pessoas possuem menor reserva emocional para o enfrentamento da doença e isso se reflete na sua 
autoestima, de modo especial em pais separados, pois estes percebem-se com menor controle sobre a própria vida. Foram identificados alguns fatores estressores que predispõem estes indivíduos a problemas psicológicos tais como: sentimento de culpa, piedade do outro parceiro, medo de explicar sobre a DMD para seu filho. Metade dos casais participantes desta pesquisa experimentava conflitos acerca de como cuidar da criança, como discipliná-las, fadiga constante e percebiam influências da família estendida. Os autores ainda discorreram sobre os mecanismos de enfrentamento destes casais que incluíram desde a negação e pensamentos mágicos sobre a melhora do filho, como também a superproteção. Seus resultados mostraram o deslocamento do sentimento de raiva, oriundo da doença, para o outro parceiro ou outras crianças da família, sendo que as mães demonstraram maior sentimento de culpa em decorrência da transmissão genética da doença. Os pais relataram mais sentimentos de tristeza resultantes da perda do filho esperado, exibindo maiores dificuldades de aceitação da doença. Estes mesmos autores citam que, para estes pais, há quatro períodos mais difíceis de enfrentar no curso da doença: a época do diagnóstico, quando cessa a deambulação da criança, a adolescência e os estágios mais tardios, quando muitas perdas são percebidas e há a possibilidade da morte.

James et al. (2006) exploraram a maneira pela qual o modo de herança de uma condição genética afeta a família, comparando familiares de pessoas com doenças ligadas ao cromossomo $X(X L)$ - como DMD e distrofia muscular de Becker-, a familiares de pessoas com doenças decorrentes de alterações autossômicas recessivas (AR) - como atrofia muscular espinal tipo II e III. O estudo verificou que os membros de famílias XL têm mais probabilidade de compreender o próprio risco na reprodução, sendo que as mães se mostraram mais conscientes a respeito deste risco. Elas também se mostraram mais preocupadas com as futuras gerações do que o grupo com condições $A R$; sentem-se significativamente mais culpadas que os pais do mesmo grupo e as mães AR; além disso, os pais XL tendem a admitir que 
culpam a mãe da criança; e os familiares XL também sentem-se mais estigmatizados.

A pesquisa de Erby; Rushton e Geller (2006) realizada com pais de pessoas com DMD procurou compreender suas atitudes, experiências e como estes discutem a respeito do planejamento dos cuidados nas fases mais avançadas da doença. Os resultados demonstram que há pouca familiaridade e pouca discussão sobre planejamentos de cuidados futuros em virtude de dificuldades emocionais para lidar com a questão. Houve uma significativa variabilidade nos relatos dos participantes, que demonstraram esperança nos tratamentos futuros, evitação de questões emocionalmente difíceis como a morte do filho e, até mesmo, a doença, como uma oportunidade para uma experiência de vida mais integral, com maior presença para os momentos vividos.

A DMD acarreta perdas funcionais progressivas, tornando o doente cada vez mais dependente de cuidados e, nesse sentido, Rosset (2009) aponta que existe uma relação entre a sobrecarga dos cuidadores e o grau de dependência do doente, o tempo gasto com os atendimentos/cuidados diários e o próprio adoecimento do cuidador.

Poysky e Kinnett (2009) apontam para alguns fatores que ajudam as famílias a se adaptarem ao diagnóstico de DMD e assim enfrentarem melhor esta nova condição. Um modelo de atendimento clínico que inclua cuidados dispensados não só ao paciente com DMD mas, também, à família, embora o cuidado centrado nesta última seja um desses fatores adjuvantes. Salienta que estes serviços de atendimento devem incluir uma coleta de informações constantes acerca da evolução e satisfação deste público e que devem atentar para uma boa via de comunicação entre equipe e pessoas atendidas.

Entretanto, apesar de todo avanço científico, até o momento a cura da DMD ainda não é possível. A DMD acarreta inúmeras perdas e involução sistemática na saúde do doente que, juntamente com seus familiares, sofre por isso, do mesmo modo que todos eles - doente e familiares - sofrem por saber que as medidas terapêuticas disponíveis não 
podem evitar a evolução do quadro clínico. Todo o sistema familiar precisa aprender a lidar com as reações e sentimentos despertados pela doença, cuja presença também interfere nas relações familiares, bem como no exercício da paternidade.

Até meados do ano 2000, a literatura apontava para uma escassez de trabalhos científicos que investigassem os genitores e seu papel no sistema familiar (DESSEN; LEWIS, 1998; SILVA; DESSEN, 2003), havendo um predomínio nos estudos com a díade mãe-fillho. Dessen e Lewis (1998), em trabalho sobre crianças com síndrome de Down e suas famílias, reforçam a necessidade destes estudos como sendo de fundamental importância para a compreensão do funcionamento da família e das interações existentes no mesossistema. Ainda afirmam que a família não pode ser examinada como um sistema isolado e que há que se levar em consideração não somente características individuais, as interações familiares e as mudanças no ambiente mais próximo, mas, inclusive, o contexto social mais amplo.

Outro ponto de grande importância é saber das estratégias de enfrentamento do diagnóstico, como atitudes, adaptações comportamentais e cognitivas diante da demanda, que vão além dos recursos pessoais (Beltrão et al.,2007). Esclarecimentos adequados sobre a doença, apoio social e contato com a espiritualidade têm se mostrado fatores que favorecem o enfrentamento.

Kohlsdorf e Costa-Júnior (2008) destacam que para se enfrentar situações problemas pode-se utilizar de vários recursos, sendo, alguns deles, o suporte social e a religião.

Acerca da religiosidade e suas correlações com a saúde mental e física, entendendo a religiosidade como um sistema organizado de crenças, valores, rituais e símbolos que facilitam a proximidade com Deus e a transcendência, os estudos de Moreira-Almeida et al. (2006) e Luchetti et al. (2011) oferecem interessantes contribuições. Estes autores encontraram que a religiosidade está associada a bem-estar psicológico, otimismo e esperança, favorecendo um estilo de vida com atitudes mais 
benéficas à saúde, diminuindo o abuso de substâncias, funcionando como suporte social, bem como, por meio de rituais, ajuda as pessoas a lidarem com a ansiedade, medos, frustrações, raiva, anomia, sentimentos de inferioridade, desempoderamento e isolamento. De acordo com estes estudos, a religiosidade foi usualmente associada a fatores que protegem a saúde mental e mesmo física dos indivíduos.

Portanto, torna-se de grande importância a pesquisa que favoreça a compreensão da vivência da paternidade no contexto da doença, das interações familiares, visando obter informações relevantes para se ajudar a família como um todo, visando a uma melhor adaptação psicológica. 
2 OBJ ETI VO 



\subsection{Objetivo geral}

Esse trabalho teve como principal objetivo conhecer a vivência da paternidade por parte de pais cujos filhos apresentam diagnóstico de Distrofia Muscular de Duchenne.e as consequências da presença da doença nas interações familiares.

\subsection{Objetivos específicos}

- Conhecer os efeitos do diagnóstico e prognóstico de Distrofia Muscular de Duchenne no pai;

- Conhecer as reações emocionais e sentimentos desencadeados em decorrência do diagnóstico do filho;

- Conhecer como o pai percebe as interações familiares após a ocorrência do diagnostico;

- Conhecer a concepção do pai sobre paternidade e, de modo específico, sobre a paternidade em relação a um filho especial. 
3 MÉTODO 



\subsection{Participantes}

Estabeleceram-se para este estudo os seguintes critérios de inclusão: pais de meninos diagnosticados com Distrofia Muscular Duchenne ( DMD) há pelo menos 2 anos, com idade igual ou superior a 10 anos. Estes critérios foram utilizados para garantir um tempo maior de convivência com a doença e, consequentemente, com as perdas relativas à sua progressão.

Para se obter os participantes foi necessário aguardar a autorização do comitê de ética em pesquisa do Hospital das Clinicas de Ribeirão Preto/USP. Após a autorização, solicitou-se à médica responsável pelo ambulatório de doenças neuromusculares (NEMI) - que atende pacientes de todo o Brasil- a indicação de pacientes que tinham diagnóstico confirmado de DMD, além de preencherem os critérios pré-estabelecidos de inclusão. Concomitantemente contatou-se também a Associação de Amigos de Portadores de Distrofia Muscular (AADM) e solicitou-se à presidente sua colaboração, no sentido de indicar, entre seus afiliados, os pais que atendiam aos critérios deste estudo.

De posse destas informações, os pais foram contatados por telefone, informados sobre os objetivos do estudo e convidados a participar ; e, quando concordavam, agendava-se um horário de acordo com a conveniência do participante, para a realização da entrevista, que aconteceu face-a-face, na sua residência.

Para se determinar o número de participantes desta pesquisa, optou-se pelo critério de saturação dos dados (MUCCHIELLI, 1990; MINAYO, 1993) que foi alcançado com 8 pais. Este critério preconiza que, após um período da coleta de dados, o assunto se esgota, não aparecendo conteúdos novos na verbalização dos participantes. 


\subsection{Descrição dos participantes}

Participaram deste estudo oito pais de filhos homens diagnosticados com DMD. A seguir, apresenta-se a descrição dos participantes, incluindo informações como idade, nível de escolaridade, estado civil e uma breve descrição da família.

É importante ressaltar que os nomes utilizados são fictícios, preservando-se o anonimato dos participantes e de seus familiares.

P1: 65 anos, possui nível fundamental de escolaridade, casado. Tem dois filhos, um deles, Marcelo, 31 anos é o segundo filho do casal, diagnosticado com DMD. Sua outra filha é casada e não reside mais com os pais. É pequeno empresário e a remuneração obtida nesta ocupação é a única fonte de renda da família.

P2: 50 anos, possui nível superior de escolaridade, atualmente na segunda união conjugal. No primeiro casamento teve 2 filhas e, na segunda união, dois filhos, sendo um do sexo masculino, Henrique, com 10 anos e diagnosticado com DMD e uma do sexo feminino, com 8 anos de idade. É comerciário, trabalha em uma cidade da região. Sua remuneração é a única fonte de renda da família.

P3: 55 anos, possui nível fundamental de escolaridade, casado. Tem três filhos, sendo que dois deles, Tiago e Pedro, com 23 e 25 anos respectivamente, diagnosticados com DMD. Sua outra filha é casada e não reside mais com os pais. É ferroviário e a remuneração obtida nesta ocupação é a única fonte de renda da família.

P4: 45 anos, possui nível fundamental de escolaridade, divorciado. Tem dois filhos. Um filho, Lucas, de 14 anos, com diagnóstico de DMD e uma filha de 10 anos. Os filhos moram com a mãe, mas o pai mantém 
contato diário com eles, participando da sua rotina. É comerciário e a renda familiar é composta pelos recebimentos do pai e da mãe.

P5: 40 anos, possui nível médio de escolaridade, casado. Tem dois filhos, uma filha de 18 anos e um filho, Marcos, de 14 anos, diagnosticado com DMD. É profissional autônomo e a remuneração obtida com sua ocupação é a única fonte de renda da família.

P6: 35 anos, com nível fundamental de escolaridade, casado. Tem dois filhos, Matheus de 10 anos e Marcos de 4 anos, ambos diagnosticados com DMD. É comerciário e a renda familiar é composta pela remuneração do pai e da mãe.

P7: 37 anos, possui nível médio de escolaridade, casado. Tem dois filhos, João, de 12 anos, com diagnóstico de DMD e uma filha de 15 anos. É profissional autônomo e sua remuneração é a única fonte de renda da família.

P8: 38 anos, possui nível fundamental de escolaridade, casado. Tem dois filhos, Márcio, de 15 anos, com diagnóstico de DMD e uma filha de 13 anos. É comerciário e sua remuneração é a única fonte de renda da família.

Com relação à renda familiar, 6 pais neste estudo declararam renumeração entre 3 e 6 salários mínimos e 2 pais declararam renda mensal de 6 a 10 salários.

\subsection{A entrevista: instrumento utilizado para a coleta de informações}

Em consonância com os objetivos desta pesquisa, optou-se pelo uso da entrevista semiestruturada, visando, deste modo, obter as informações 
por meio dos conteúdos verbalizados, sobre os sentimentos e vivências subjetivas dos pais.

De acordo com Minayo (1993), a entrevista é a técnica de "colheita" de informações mais utilizada no trabalho de campo. Por meio dela podem-se obter duas classes de informações: as objetivas, que podem ser levantadas por meio de outras fontes de dados e as subjetivas, que incluem o sistema de representações, crenças e valores inerentes à fala.

Para Biasoli-Alves (2003), a entrevista tem sido uma forma de coleta de dados bastante utilizada em psicologia, ciências sociais e outras áreas, tendo como ponto fundamental a possibilidade de obtenção de informações internas ao sujeito. Por meio da entrevista obtêm-se informações sobre atitudes, sentimentos e valores subjacentes ao comportamento, permitindo, assim, um conhecimento mais aprofundado acerca da questão pesquisada, contextualizando a ação e indo além de conteúdos descritivos (informação verbal) ${ }^{2}$.

Além disso, uma entrevista bem realizada permite levantar informações acerca do modo como o sujeito percebe e significa sua realidade e compreender como se estabelecem relações em determinado grupo, além da oportunidade para observar uma porção da vida do entrevistado manifestada na relação bipessoal que envolve a entrevista (BLEGER, 2003; DUARTE, 2004).

Para a realização da entrevista, foi elaborado um roteiro semiestruturado, que permite uma análise qualitativa, mais ampla e profunda dos dados subjetivos relatados (LÜDKE; ANDRÉ, 1986; MUCCHIELLI, 1994; BIASOLI-ALVES, 1998).

As questões mais objetivas do roteiro (anexo 1) visam obter informações a respeito dos aspectos socioeconômicos e culturais das famílias.

As perguntas abertas do roteiro mantêm a flexibilidade necessária para que se estabeleça uma interação mais adequada entre entrevistador/entrevistado e permitem ao sujeito expressar sua vivência,

\footnotetext{
${ }^{2}$ Biasoli-Alves, Z.M.M. Entrevista: formatos e análises. Material para aula não publicado, 2003
} 
lembranças, fantasias, expectativas, sentimentos, enfim, dados subjetivos que apenas o sujeito pode relatar. Petean (2004) salienta que, ao fazer perguntas ao entrevistado, pode-se facilitar a produção dos relatos sobre suas vivências. Assim, foram selecionados temas que suscitassem a verbalização do modo de pensar ou de agir dos participantes: informações sobre a gestação; sobre o diagnóstico; as mudanças ocorridas na rotina diária e de cuidados com o filho em decorrência da distrofia; mudanças percebidas nas interações após o diagnóstico da doença; a concepção sobre a paternidade e a paternidade especial.

Para elaborar o roteiro da entrevista, as questões foram construídas de modo a evitar manifestações defensivas por parte dos entrevistados e, de acordo com a literatura, o roteiro foi submetido a um pré-teste, para avaliação de sua viabilidade, adequação e compreensão (MUCCHIELLI, 1978; LÜDKE; ANDRÉ, 1986; FLEITH; COSTA JÚNIOR, 2005). 
4 PROCEDI MENTOS 



\subsection{Pré-teste}

O roteiro foi submetido a pré-testes com dois pais que foram incluídos neste trabalho, embora esta etapa metodológica visasse avaliar a viabilidade, adequação e compreensão do roteiro de entrevista. Como resultado, o roteiro sofreu alterações: alguns itens foram acrescentados, outros excluídos e alguns alterados para adequações de linguagem. 0 detalhamento das modificações feitas encontra-se no anexol deste trablho.

Após proceder-se às alterações, obteve-se o roteiro final (Anexo B) que foi utilizado para coleta de dados.

\subsection{Procedimento para Coleta de Dados}

O primeiro contato foi realizado por telefone. Nesta ocasião, explicavam-se para os pais os objetivos da pesquisa e estes eram convidados a participar. Havendo a concordância, agendavam-se o dia e a hora para a realização da entrevista.

Antes do início das entrevistas, explicavam-se novamente os objetivos da pesquisa, e o termo de consentimento (Anexo 3) era assinado. As entrevistas foram realizadas nas residências dos participantes, em hora e dia agendados de acordo com sua conveniência.

Todas as entrevistas foram gravadas em áudio, tendo a duração média de 1:00 h. Em seguida, foram transcritas na íntegra, preservandose o anonimato.

\subsection{Procedimento para análise}

Este é um estudo exploratório, descritivo, de natureza qualitativa e, sendo assim, optou-se pela análise temática de conteúdo. A opção por 
este método se deve ao fato de que ele é considerado o mais adequado para atender aos objetivos propostos, visto que, de acordo com Minayo (2007), não busca generalizações, mas sim o aprofundamento e abrangência da compreensão sobre as vivências dos participantes.

A análise de conteúdo é um procedimento sistemático para a obtenção do conteúdo das mensagens, de indicadores e, por fim, do conhecimento, cujas origens, historicamente, se situam num modelo científico positivista, que busca o rigor da objetividade (MINAYO, 1993). Sua evolução, como técnica, ainda se desenrola em meio ao debate entre a objetividade e cientificidade e o significado da informação, do quantitativo e do qualitativo.

Para realizar a análise, o pesquisador mergulha no material coletado em busca de núcleos de sentido presentes no conteúdo. Configura-se por três fases distintas: a pré-análise, a exploração do material e a análise do discurso.

$\mathrm{Na}$ fase da pré-análise, o foco é retomar os objetivos da pesquisa com vistas a encontrar indicadores que possam orientar a interpretação do material. Emergem nesta etapa as unidades de registro que serão analisadas. A seguir, é realizada a exploração do material, processo em que se fazem a codificação e contagem das unidades de registro para nortear a escolha dos temas. A seguir, processa-se a análise do discurso uma técnica utilizada para apreender o significado e seu processo de construção, com base no material coletado. Esta técnica insere-se especialmente nas ciências sociais e pretende extrair a ideologia subjacente ao texto, bem como a subjetividade desvelada pela linguagem ou até mesmo pelo silêncio. Por fim, processam-se o tratamento e a interpretação das informações obtidas.

A escolha dos temas, segundo Campos (2004), é feita pelo pesquisador, procurando-se atender aos objetivos da pesquisa e incluindose os sentidos emergentes tanto no contato com o material estudado quanto na literatura utilizada como referencial teórico. 
5 RESULTADOS E DISCUSSÃO 

Neste capítulo são apresentadas algumas considerações a respeito dos pais participantes e seus filhos, seguidas da análise e discussão dos dados das entrevistas.

Os filhos dos pais entrevistados, na sua maioria, já haviam perdido a capacidade de deambulação e utilizavam cadeiras de roda para a locomoção. Apenas uma das crianças (P8) estava em fase de adaptação à cadeira de rodas.

Houve entre os pais participantes uma variação grande sobre o tempo de convivência com a doença do filho. O pai caracterizado como tendo um filho em idade mais avançada (P1) vem enfrentando a doença há 27 anos, e sua vivência é bastante distinta da vivência de outros pais com filhos mais novos.

\subsection{Diagnóstico}

Neste tópico serão discutidas questões relacionadas ao evento do diagnóstico, incluindo-se as fases: pré-diagnóstico, comunicação do diagnóstico e pós-diagnóstico. Serão apresentados e comentados os relatos dos pais a respeito de suas percepções e reações, vivenciadas nessas três fases. Na fase de pré-diagnóstico, observam-se dois tipos distintos de pais: aqueles que notaram diferenças no desenvolvimento motor de seus filhos precocemente, indo em busca do diagnóstico e aqueles que só perceberam a doença quando os problemas motores característicos da distrofia estavam evidentes. Serão abordados, também: o problema da demora em se encontrar um diagnóstico definitivo, o que gera ansiedade, angústia e incertezas por parte da família como um todo; - desconhecimento sobre $o$ diagnóstico e suas consequências; a idealização dos pais em torno do filho imaginado e seu desapontamento diante de um filho real, vitimizado por uma doença crônica; as dificuldades de compreensão do diagnóstico, revelando os diversos 
sentimentos desencadeados pela "escuta" do diagnóstico e que dificultam a compreensão e assimilação das informações médicas; o desencadeamento de processos defensivos de negação da doença e a busca de tratamentos alternativos, visando a uma cura miraculosa; as consequências dessa tentativa de cura; a forma adequada de se transmitir o diagnóstico, admitindo-se a possibilidade de que a postura baseada no conhecimento científico e o reforço dado à cronicidade e letalidade da DMD, pelos profissionais da área médica, tentando negar aos pais o exercício de seus valores e crenças religiosos, talvez não seja a postura mais adequada ao momento de comunicação do diagnóstico, sendo a religiosidade uma das poucas fontes de esperança e de suporte que os pais têm nesta hora.

Alguns pais relataram que, desde que os filhos eram pequenos, já notavam diferenças no seu desenvolvimento, em relação a outras crianças e que, em virtude dessa percepção, partiram em busca de um diagnóstico médico. Outros relataram que só perceberam a existência de algo incomum quando alguns sinais mais evidentes, como o aumento da panturrilha e o agravamento dos problemas motores apareceram.

"Havia alguns amigos da minha filha e iam para minha casa que começava a comparar e víamos que existia algum problema. Levávamos aos médicos em (cidade) e ele falava que o problema era este, aquele... No fim, eles não souberam concluir um diagnóstico". (P2)

“nossa, ele caía muito, não sabia por quê; eu achava que era problema de vista e aí foi no oftalmo, e vai, leva no ortopedista, leva num, leva noutro e nada. Foi passando, passando, aí caiu num neurologista, foi aonde que descobriu". (P5)

"quando ele fez quatro anos que a panturrilha dele começou a aumentar e nós percebíamos que criança mais nova subia na cadeira, ele não subia, ele corria, ele caía com facilidade, e a gente começou a ficar preocupado, primeira coisa que nós pensamos vamos levar ele num ortopedista, marquei 
uma consulta e levei ele no ortopedista, o ortopedista já percebeu que era uma coisa grave." (P4)

Os relatos mostram que alguns deles notaram diferenças no desenvolvimento motor de seus filhos precocemente, antes dos quatro anos de idade e consultaram médicos para que realizassem o diagnóstico. Outros relataram que só perceberam quando os problemas motores característicos da distrofia estavam evidentes. Estes dados corroboram com os encontrados por Moreira e Araújo (2009) em seu estudo. Os autores salientam a dificuldade que os pais encontram para obter o diagnóstico definitivo, tendo que consultar vários profissionais. A "demora" e o longo tempo entre a percepção dos sintomas e o diagnóstico, aliados aos diversos exames pelos quais a criança tem que passar, geram ansiedade, angústia e incertezas.

Após a percepção do desenvolvimento "anormal" do filho, os pais entram em contato com a perda do filho imaginado/idealizado. Muitas são as expectativas depositadas nesse descendente, tais como a possibilidade de galgar e alcançar uma condição melhor que a do pai no futuro, seja em termos educacionais ou de formação profissional, a perpetuação da família em seus descendentes, de serem fonte de satisfação na troca afetiva, entre outras. Um desenvolvimento que acontece fora do esperado desencadeia o processo de luto do filho imaginado e os pais experimentam a angústia e a incerteza sobre o futuro. Segundo Goes (2006), a deficiência do filho elicia dificuldades psíquicas nos pais, pois estes não conseguem encontrar, no filho real, traços do filho ideal, dificultando o processo de identificação. Um estudo de Krob et al. (2009), realizado com pais de bebês que estavam no segundo mês de vida, mostrou que desde a gestação, os pais vão criando a imagem deste filho, imaginando suas características físicas e de temperamento. Estes pais revelaram suas expectativas em termos do exercício da paternidade, das interações que estabeleceram com os filhos e se mostraram atentos ao desenvolvimento físico deles. Apesar de se tratar de fases diferentes de 
vida dos filhos, depreende-se que os pais deste estudo já haviam se defrontado com o filho real, em relação ao qual tanto o advento da doença como a percepção do desenvolvimento diferente do esperado acabam por remetê-los ao mesmo processo de perda do filho esperado.

O desconhecimento sobre o diagnóstico e suas consequências foi relatado por todos os pais.

“Quando foi diagnosticado, não sabíamos nada, na realidade. Tenho uma irmã que é psicóloga e uma filha que é formada em Biomedicina que pesquisaram (sobre a doença) e me deram as informações. Porque eu não tinha nem ideia da gravidade do caso. Eu fiquei sabendo porque elas pesquisaram e disseram [...] Acho que o médico também disse, mas muito pouco". (P2)

“Essa palavra, eu nunca tinha contato com alguém com distrofia na minha família e nem na família dela, nunca tinha ouvido falar disso, certo? Eu acho que era problema de nervo, que ia entortando os nervos e tal. Aí depois que eu fui descobrir que, sabe assim, que vai caindo e o médico falou, "Não adianta fazer promessa, entendeu? Não acha que vai levar no centro espírita e vai resolver, não vai, entendeu? Nem lá em Aparecida, não vai resolver o problema, é assim, assim e assim". (P5)

Os relatos mostram que alguns pais não se sentiram suficientemente esclarecidos sobre o diagnóstico. O momento da notícia, a "escuta" do diagnóstico desencadeou diversos sentimentos que dificultaram a compreensão e assimilação das informações médicas. Os pais falaram sem clareza sobre o momento do diagnóstico, como no relato "acho que o médico também disse"(P2) e revelam que é preciso um tempo para a assimilação das informações, o que sugere a emergência de defesas do psiquismo.

Os estudos de Firth (1983), Petean (2004), Camargo e Londero (2008), Poysky e Kinett (2008) e Chacon (2011) revelam que ao receber o diagnóstico de doenças crônicas, graves ou que tenham impacto importante sobre a saúde do filho, os pais experimentam reações intensas 
que acabam interferindo no modo como assimilam estas informações.

Um pai relatou que, na tentativa de melhorar a saúde do filho, adotou procedimento inadequado quanto ao tratamento, atribuindo este fato à falta de experiência ou orientação médica adequada.

“É... por falta de experiência, eu achei que ele fazendo algum exercício, por falta de informação médica também, achei que o exercício ia ajudar e dificultou muito porque ele foi perdendo a formação, a pequena formação muscular que ele tinha, pequenos exercícios, ele foi perdendo isso rapidamente no desenvolvimento da doença". (P1)

É provável que em virtude da vivência dolorosa causada pelo diagnóstico, os pais tenham desencadeado um processo defensivo da negação, pois acreditam que a criança possa melhorar e vão em busca de tratamentos miraculosos e da cura. Neste sentido, Camargo e Londero (2008) afirmam que os pais, ao tentarem melhorar as condições de saúde do filho sem terem recebido as devidas orientações, ou sem as terem compreendido, acabam tomando iniciativas próprias que, ao invés de melhorar, podem ser prejudiciais à saúde da criança.

A notícia de deficiência da criança, de uma doença crônica ou de outras condições que interferem no seu desenvolvimento saudável, carece de esclarecimentos e informações precisas nesta hora, com linguagem simples, para que os pais possam assimilar o que foi dito e elaborar o luto do filho ideal perdido. (POYSKY; KINETT, 2008; CAMARGO; LONDERO, 2008; BELTRÃO et al., 2007; MURATA; PETEAN, 2000; BRUNHARA; PETEAN, 1999).

A forma e o momento do diagnóstico foram relatados pelos pais.

“[...] eu acho que o filho da senhora tem uma doença assim, assim, e falou tudo para ela, falou uma bomba, já soltou na mão dela, não omitiu nada não, aí foi fazer exame e realmente deu distrofia. Esse dia, para a gente, foi um dia muito difícil, para mim. [...] o conhecimento da doença, do diagnóstico, foi um sofrimento muito grande, foi uma bomba que a gente teve na mão 
[...] a gente falando em distrofia muscular a pessoa abria o livro e fechava o livro. Olha, é água com muita fé, isso resume tudo, entendeu?". (P1)

“Infelizmente, seu filho tem uma doença degenerativa, expectativa de doze a vinte e cinco anos, não tem cura, não tem tratamento, não tem remédio e não há o que fazer". Minha esposa ficou olhando para ele, "E é isso mesmo, já está diagnosticado e a única coisa que eu preciso indicar é fisioterapia passiva e acabou". Daí nós saímos tontos, nosso filho tem problema, foi assim que eu descobri". (P4)

Diante da dor causada pela confirmação do diagnóstico da DMD os pais ficaram atônitos, não conseguindo exibir qualquer comportamento, pois receberam a notícia abruptamente, segundo a sua percepção.

A forma como o diagnóstico é informado interfere na aceitação ou rejeição da criança e na adaptação da família à doença, sendo necessárias medidas de humanização nos serviços de saúde e conhecimento dos profissionais da área acerca das reações e mecanismos de defesa que vigoram neste momento (CAMARGO; LONDERO, 2008; MURATA; PETEAN, 2000).

No relato dos pais nota-se que os profissionais da saúde, no intuito de conscientizá-los sobre a gravidade da doença, adotam uma postura baseada no conhecimento científico, procurando reforçar a cronicidade e letalidade da DMD, temendo que valores e crenças religiosos possam legar a esses pais a expectativa de uma cura ilusória. Como exposto nesta fala: "Não adianta fazer promessa, entendeu? Não acha que vai levar no centro espírita e vai resolver, não vai, entendeu? Nem lá em Aparecida, não vai resolver o problema $[\ldots] "$. Contudo, cabe o questionamento sobre este proceder no momento doloroso da "escuta" da notícia, visto que a religiosidade é uma das poucas fontes de esperança e de suporte disponível aos pais nesta hora.

A reação de choque foi relatada como grande sofrimento, acompanhada de sentimentos de impotência e de confusão. 
“Foi um choque! Porque nunca esperamos [...] sempre o vizinho tem, não com a gente. Realmente foi um choque saber da gravidade da doença e qual é o caminho natural da coisa... E você vê um moleque cheio de vida... e pensar que daqui a pouco não tem nada disso... Realmente, é complicado para a minha cabeça.... Foi um baque muito grande quando aconteceu".(P2)

“O choque foi quando fomos em São Paulo, depois de muitos anos, a segunda vez, nós tinha ido, inclusive num médico particular de São Paulo, fazer os exames e ele garantiu que não tinha problema nenhum, aí nós fomos na USP e fizeram a biópsia em todos nós iii e quando deu a notícia que eles realmente tinham distrofia, que eles iam para cadeira tal, tal, é, foi difícil, mas a gente sempre se agarrou a Deus [...] quando nós távamos na volta do, da USP, eu parei o carro no estaciona..., no acostamento, a gente tava tudo muito abalado ainda, foi um choque muito forte". (P3)

A reação de choque foi a mais verbalizada pelos pais deste estudo, semelhante ao que ocorreu nos estudos de Brunhara e Petean (1999), Petean (2004), Camargo e Londero (2008) e Poysky (2008). Outras reações podem estar associadas (CAMARGO; LONDERO, 2008) como reações de surpresa, dúvida, negação e revolta. Kluber-Ross (1995) descreve a reação de choque que é eliciada pela notícia de uma doença ou frente às perdas significativas como uma reação temporária e que dará lugar a outras defesas posteriormente. Esta reação está relacionada com o conteúdo da notícia, no caso o diagnóstico, mas também com a forma como esta notícia foi dada.

Os pais relataram também outros sentimentos coexistentes à reação de choque.

“porque hoje o cara pode ter milhões e não ter nada. A chance da cura da distrofia é a mesma porque não tem o que fazer. Você pode dar uma consistência, dar um suporte grande para o seu filho com um enfermeiro do lado e tudo, mas a cura não". (P1) 
“[...] eu fiquei completamente arrasado, principalmente pelo fato de não se ter, hoje, perspectiva de nada. (Se) Você fala que vai ter um tratamento que resolve, não vai ser normal, mas tem tratamento... Você saber que não tem tratamento hoje, que antes de vinte anos falecer, é complicado". (P2)

"não vou te dizer que não tive algumas horas de desespero, de vontade de acabar com a vida, independente, isso aí, todo ser humano uma hora passa por isso, mas eu consegui passar, mesmo tendo essa, umas horas de recaída". (P3)

"Sabe quando você tá num lugar, onde você vê um túnel que não tem saída? E você fica pensando: - Puxa, o que vai ser do meu filho, o que vai ser de mim?". (P4)

“Meu mundo acabou [...] Você é um grão de areia”. (P6)

Sentimentos de desespero, impotência e desesperança também foram relatados, bem como o desejo da própria morte. Frente ao diagnóstico de uma doença crônica incurável, reações como estas são esperadas e têm sido descritas na literatura (BRUNHARA; PETEAN, 1999; PETEAN, 2004).

Quando questionados sobre o futuro, os pais falaram pouco sobre as expectativas de vida dos filhos, demonstrando a dificuldade em lidar com a previsão da morte; sentem-se confusos ao falar sobre o assunto.

“[...] até que ponto vai isso, que em número de idade eu acho que são poucos que chegam a essa idade né? Então, eu entendo que ... às vezes eu até me perco um pouco você já percebeu, você é psicóloga, você sabe, eu tô conversando eu me perco um pouco, que é muita coisa".(P1)

"O que eu encaro com o Renato não é um problema, de jeito nenhum, o que tiver que acontecer, vai acontecer e ponto. O que eu sei (pausa) ...difícil falar (pausa seguida de choro)". (P7) 
“Então quer dizer, hoje em relação ao Ricardo, eu sei o que que tá para vir, mas é uma coisa que não tem, não, não tem como fugir disso, escapar disso, coisa que, o que vier (Pausa)". (P5)

“você tem que estar preparado para o amanhã, eu não gosto de surpresas, eu vivo o hoje com ele, amanhã eu não quero saber". (P6)

Nos relatos, os pais demonstraram que conhecem o curso da doença, sabem das etapas subsequentes, as perdas funcionais e progressivas que acometem as crianças. No entanto, não conseguem verbalizar sobre o futuro. Suas falas tornam-se reticentes e confusas, emocionadas. Sabem o que está por vir, estão cientes da necessidade de preparar-se para isto, mas evitam falar sobre o assunto que gostariam de não saber.

Percebe-se o conflito existente na esfera afetiva, pois, os conhecimentos objetivos acerca do prognóstico da doença, o falar sobre ele os fazem entrar em contato com uma realidade temida que não querem ver se concretizar. Como expõe Kluber-Ross (1995), o processo de luto implica fases que se processam, não de modo linear. Apesar de demonstrarem em seus depoimentos que estão enfrentando e se adaptando à realidade da doença, quando questionados sobre o futuro, o processo defensivo da negação torna a revelar-se, como na fala de um pai “amanhã eu não quero saber".(P6)

A impossibilidade de cura e o prognóstico de degeneração progressiva e letal acarretam frustração e angústia nos pais, que se veem impotentes e subtraídos de qualquer poder para minorar a situação, visto que não há tratamento possível até o momento que possa conter o curso da doença e a perspectiva de morte do filho ainda na juventude. 


\subsection{Significado atribuído à doença}

Aqui serão discutidos: a necessidade dos pais de buscar justificativas ou sentidos para a doença; a atribuição da culpa a alguém do núcleo familiar; o significado de missão diante da doença; o sistema de crenças e valores dos pais, que permeia a justificativa da doença.

Apesar do conhecimento científico sobre a causa da DMD, os pais sentiram necessidade de encontrar uma justificativa, um sentido para a doença do filho, confrontando e até mesmo colocando em dúvida a explicação científica que receberam.

“Culpa minha? Culpa da Elizabeth? Não, vamos colocar que tinha uma origem hereditária, não teve, a genealógica não diz isso, né? [...] Porque, o fundamento original seria a árvore genealógica, a família sua tinha, a terceira geração teve um primo assim, no pai não teve. [...] Dado um diagnóstico técnico seria uma mutação, vamos colocar, seria uma mutação na formação do gene, tudo isso, eu questionei muito comigo mesmo e com Deus". (P1)

“Minha opinião é que foi uma mutação genética, eu não acho que a minha esposa é portadora, não acho, nós não tivemos nenhum caso na família, nem um irmão dela, nem uma irmã dela, uma tia, uma vó, um parente qualquer que nós conhecemos que teve um filho com qualquer tipo de doença parecida. [...] A outra opinião é a religiosa que eu tenho, de que nada acontece por acaso, sabe, o homem, o homem é muito cético. $O$ homem é muito pragmático, ele é materialista, o homem ele acha que ele pode encontrar a causa e a razão de todas as coisas. Mas na verdade eu não acredito nisso". (P4)

Outro pai atribuiu a culpa da doença do filho à sogra, que sabia da existência da patologia na família da mãe ${ }^{3}$ e não avisou o casal antes de terem filhos, negando-Ihes a possibilidade de escolha.

\footnotetext{
${ }^{3} \mathrm{~A}$ mãe da criança com DMD é filha adotiva, por isso desconhecia os antecedentes familiares.
} 
“Ela decidiu o futuro dele [...] ela não devia ter feito isso [...] a gente foi traído. [...] Será que era eu que tinha que ser o pai dele?". (P6)

Para alguns pais a doença passou a ter o significado de missão a ser cumprida por eles ou pelo próprio filho, designada por Deus.

“Mas a gente foi chamado a servir. Eu entendo que problema todo mundo tem, tem gente reclamando de unha encravada, tem gente sem um braço e sem uma perna sorrindo, desempregado, desamparado, né? Então eu fui escolhido, eu, a Elizabeth. Eu acho que a gente foi escolhido para essa situação, foi, tipo assim, eu tô vendo Deus falando assim, eu vou te dar esse para você cuidar, eu quero ver o que você vai fazer com ele, você vai viver com isso ou vai morrer por isso né? Hoje eu entendo assim, e toda vez que eu entendo assim, me autoafirmo, menos eu sofro". (P1)

"Deus falou, ah, é o caminho de vocês, vocês têm que criar, ai, e lutar, e, realmente, mas ... É a vida". (P3)

“[...] a minha certeza maior é de que Deus, cada um de nós vem nessa terra e a gente não sabe, mas Deus manda essas pessoas com a minha opinião, que ele envia, não só o meu filho, mas todos os outros portadores de outras doenças, pessoas que são anjos que vêm na terra para tentar modificar o coração das pessoas no mundo." (P4)

Os relatos mostram que o significado da doença está permeado pelo sistema de crenças e valores dos pais e, de modo especial, pela sua religiosidade que, neste estudo, atuou como fator facilitador ou de proteção para estes pais, ajudando-os a enfrentar a doença e o cotidiano. Supõe-se que para estes pais, assim como para as pessoas em geral, a doença, os acidentes, as dificuldades da vida sejam percebidos como uma punição divina. Quando atribuíram o significado de missão a ser cumprida, os pais conseguiram não somente aplacar os sentimentos de raiva dirigidos a Deus como também atenuar a noção de que a doença do filho 
foi-lhes imposta como uma punição. Desse modo, reconciliam-se com Deus, salvaguardando-o com uma imagem de "Pai" protetor e justo, a quem podem recorrer nos momentos de dor. Admitida a impossibilidade de se proceder à cura por meios científicos, a religiosidade é a única fonte de esperança destes pais. Na literatura (BOUSSO et al., 2010; WORTMANN; PARK, 2008), a religião mostrou-se como um instrumento que ajuda a explicar e dar significado às experiências de doença e morte, auxilia a família na aceitação, na adaptação e no ajustamento.

\subsection{Enfrentamento}

Nesse item pretende-se apresentar os seguintes aspectos relacionados ao enfrentamento da doença: os diferentes recursos utilizados pelos pais, como a busca de informações sobre o tratamento e a cura da doença; a opção pela não adesão ao tratamento; a religiosidade como recurso de enfrentamento para o sofrimento e a esperança de milagre por parte de alguns pais; a proatividade de determinados pais na obtenção de recursos financeiros e de suporte social, visando conseguir equipamentos e garantir melhor adaptação, qualidade de vida ou sobrevivência para os filhos.

Os pais se utilizaram de recursos diferentes para enfrentar a DMD do filho. Alguns foram em busca de informações sobre o tratamento e cura da doença.

“eu estou sempre atrás de me informar, de ler, eu liguei para a Elizabeth, eu liguei para a Doutora Amanda, eu liguei para a fisioterapeuta, eu liguei para todo mundo, eu fui atrás, sabe, eu tô atrás desse equipamento que é moderno que não tem no Brasil, se eu não conseguir ele pela, pelo Ministério Público, eu vou tentar pela igreja". (P4) 
“Tinha uma vacina, que foi descoberta nos Estados Unidos, mas quando foram fazer os testes, ela não serviu para todos os tipos de distrofia e, no caso dele, serviria porque ele tem só um lapso nos elos do DNA. Serviria para ele, mas nos Estados Unidos não autorizaram porque não serviria para todos. Agora tem uma outra corrente que diz que daqui a 3, 4 anos já estão aplicando em cobaias e daqui a 3, 4 anos, se der certo". (P2)

Um pai decidiu, com base em seu conhecimento pessoal prévio e na busca das informações sobre o tratamento proposto por um médico, não aderir ao mesmo, demonstrando participação ativa na tomada de decisões.

“Mas se não for remédio (para Distrofia) eu não vou dar. Eu voltei e fui pesquisar, aí eu fui saber sobre os efeitos colaterais da cortisona. Eu falei:= Eu não vou dar. [...] E tomei a minha decisão mesmo lá. E até hoje eu não dei e eu tenho certeza que se ele tivesse tomado corticóide, agora ele tinha ido embora". (P5)

Os relatos apontam que a maioria dos pais utilizou como estratégia de enfrentamento a busca de informações sobre tratamento e cura da enfermidade do filho. Manterem-se informados propiciou uma participação ativa no tratamento dos filhos. Kolsdorf e Costa Junior (2008) referem que a busca ativa de informações mostrou-se uma importante forma de enfrentamento, que possibilita aos pais recursos para tomadas de decisão sobre o tratamento, planejamento e maior capacidade de vigilância sobre o estado de saúde dos filhos. De acordo com Hodges (2010), a aceitação da doença aparece como resultado de uma compreensão maior das condições e implicações da doença do filho, e da busca ativa para adaptações necessárias para lidar com as necessidades práticas, procurando conselhos e orientações de pais de pessoas mais velhas acometidas pela doença.

Outros, porém, falaram da esperança de um milagre que thes restaure a saúde. 
“Hoje é a única coisa que eu posso fazer, é pedir para que surja um milagre e que não seja o pior que aconteça com ele, que tenha algum tipo de cura, alguma coisa que possa melhorar". (P2)

"Queria que ele andasse. Milagre, vejo ele me abraçando e me beijando nos sonhos". (P6)

“Ele é novo ainda, pode ser que tenha um milagre da ciência pra ele, pra melhorar a vida dele". (P8)

Também mostraram-se pró-ativos na obtenção de recursos financeiros e de suporte social para conseguir equipamentos a fim de garantir melhor adaptação, qualidade de vida ou para garantir a sobrevivência para os filhos.

“eu precisei comprar para fora do país, eu tinha já essa reserva [...] já é uma coisa moderna que é um suporte respiratório, isso deu um suporte de vida sim, para ele deu para todo mundo". (P1)

“[...] graças a Deus até hoje nunca deixei faltar nada né, nada, nada, tipo eu, da cadeira, muitos desses produtos são caro, são caríssimos, ortopédico é caríssimo, [...] não consegui nada, tudo foi comprado, entendeu, com meu suor, só ganhei uma cadeira só uma vez, quando ele era menor, [...] A única ajuda que eu tenho aqui né, é que eu consegui aposentar ele né." (P6)

"a igreja me deu a cadeira de rodas motorizada, me deu a cadeira para adaptação e me deu o guincho". (P5)

"Consegui a cadeira de rodas lá no HC, não tinha condição de comprar". (P7)

Alguns pais relataram que na obtenção de aparelhos e recursos necessários para atender às exigências da doença, o fazem com recursos financeiros próprios, planejando previamente. Outros recorreram a 
entidades de assistência para consegui-los. Em ambos os casos, agindo proativamente para garantir que tais recursos sejam atendidos. Em vista da necessidade de equipamentos especiais que precisam ser adquiridos de acordo com as perdas funcionais dos filhos, semelhante às exigências de tratamento de crianças com câncer (PANGANIBAN-COLARES; MEDINA, 2011), esses pais também experimentam a sobrecarga financeira e, toda ajuda, nesta esfera, minimiza a tensão provocada por essa demanda.

A religiosidade esteve presente no discurso de alguns pais como recurso de enfrentamento para o sofrimento causado pela doença.

“[...] quando deu a notícia que eles realmente tinham distrofia, que eles iam para cadeira tal, tal, é, foi difícil, mas a gente sempre se agarrou a Deus [...]". (P3)

"você se sobrecarrega para poder ir para frente, e o que me dá força, tem uma coisa que você busca força, pra mim, Deus, é a minha fé". (P4)

"A minha força vem da igreja, eu oro muito pra Deus me dar forças". (P7)

A religiosidade teve efeito positivo no enfrentamento da doença, possibilitando aos pais que suportem a dor e a sobrecarga advindas do adoecimento e das perdas que os filhos sofrem, como descrevem também os estudos de Beltrão et al. (2007), Nascimento et al. (2009), PanganibanColares e Medina (2011). Diante da dor, a esperança de cura e o apoio da religiosidade se constituíram como uma estratégia de enfrentamento frequentemente utilizada pelas mães do estudo de Kolsdorf e Costa Junior (2008), aparecendo como "bálsamo" para seu sofrimento, configurando-se como estratégia adaptativa com efeito positivo também para os pais deste estudo. Wortmann e Park (2008) também referem em seu estudo que a religiosidade como meio de enfrentamento para as perdas tem se mostrado frequentemente como um fator positivo, ajudando as famílias quanto a uma melhor adaptação diante das situações de perdas. 
Para alguns pais, o sentido de pertencimento a uma comunidade religiosa teve também efeito positivo, pois foi um meio de inserção social importante. Continuaram a frequentar as reuniões devocionais com a família, levando consigo o filho doente que, assim, passou a ser visto e aceito neste meio. Assim, a religião entre seus membros funcionou como um suporte social importante para a família. Wortmann e Park (2008) encontraram que o suporte social recebido da comunidade religiosa teve, em sua maioria, efeito positivo sobre o ajustamento da família. Enfim, o suporte dado por parentes, amigos, comunidade e profissionais de saúde tem sido relatado como fator que favorece a elaboração de estratégias de enfrentamento, minimizando o nível de estresse (NASCIMENTO et al., 2009).

\subsection{0 cotidiano e a doença}

Nesse tópico pretende-se apresentar o comportamento dos pais diante das diferentes exigências impostas pela doença. Assim, podem-se antecipar estes comportamentos: uma posição colaborativa e participante por parte de alguns pais, assumindo engajamento diante de certas funções do cotidiano; a posição de cuidadores secundários, dando prioridade ao atendimento feito pelas mães; a posição de uma participação maior nas atividades de lazer; a posição de se colocarem mais nas tarefas que exigem maior força física, no provimento material e nas exigências e regras morais, corroborando o papel e o estereótipo mais tradicional de paternidade; a posição de disponibilidade para as necessidades de cuidado, tanto no aspecto físico quanto no aspecto emocional. Também se discutirá sobre a carga vivenciada pelos pais, seja o desgaste físico e mental, a preocupação constante, o sofrimento e a tristeza diante do enfrentamento da doença.

Alguns pais revelaram uma posição colaborativa e participante no cotidiano, diante das muitas exigências que a doença impõe. Os que se 
engajam nos cuidados com o filho assumem algumas tarefas como os cuidados de higiene, a alimentação, a locomoção.

"porque a doença cobra muito, cobra muito, é um resfriado, uma gripe, você corre e tal $[. .$.$] ajudo na higiene do Marcelo, tudo, tudo, tudo, almoço, faço$ alimentação com ele, vejo esporte no quarto com ele, converso bastante [...] trago um lanche do jeito que ele gosta, eu tô levando um lanche para você e tal, isso é rotina, é todo dia a mesma coisa, é difícil". (P1)

“Tipo assim, eu pego ele, tiro da cadeira, ponho no carro, ponho pra lavar, agora quando eu não tô, ela (a mãe) tem que se virar". (P6)

"normalmente eu vou para o clube com ele ou saio no shopping. Mas, normalmente, a coisa que ele mais adora é ir para o clube nadar, brincar. [...] Mas fora isso não tem... Porque eu chego sábado, eu chego sexta-feira à noite, perto de meia noite, uma hora. E vou domingo à tarde. Então, não tenho tempo nenhum para fazer...". (P2)

Os pais mostraram-se atentos e responsivos ao atender às necessidades dos filhos, mesmo que essas necessidades fossem difíceis de serem atendidas. Nestes relatos é possível depreender que os pais participam do cuidado dos filhos, mas, de maneiras diferentes. $\mathrm{Na}$ maioria, eles assumiram uma postura colaborativa na rotina de cuidados, procurando aliviar a carga das mães, assim como o relatado por Manfroi et al. (2011). Outros pais percebem-se como cuidadores secundários, sendo as necessidades básicas atendidas primordialmente pelas mães. Há também os que participam mais nas atividades de lazer. Para Bruschini; Ricoldi, (2012) os pais ficam, em geral, com as tarefas que exigem mais força física, com o provimento material e as exigências e regras morais, corroborando o papel e o estereótipo mais tradicional de paternidade

Os relatos revelam também que os pais estão disponíveis e atentos às necessidades de cuidado, seja em relação à rotina de cuidados físicos, seja em relação às necessidades emocionais. 
“[...] (Marcelo) começou a questionar coisa que despertou, uma moça de Alfenas que começou alguma coisa de namoro com ele né? Eu não via possibilidade alguma de, mas não podia proibir, eu achei que ela podia estar enganando ele, é um risco né? Emocionalmente né? Afetivamente? Totalmente desiludido". (P1)

“[...] eu o levava para andar de bicicleta e ele não andava. Ele não consegue andar porque a perna dele não permite. A musculatura não permite. Eu saía para ele andar um pouco na praça, na pracinha de areia [...]". (P2)

“Mas correndo atrás deles todos [...] ele foi internado duas vezes, teve para falecer, e, teve um monte de problema, de doença, fora a distrofia, sabe? Sempre tudo eu correndo, sempre eu, mesmo hoje, eu trabalho de turno [...] eu que pego eles, eu que ajudo, faço tudo, comigo não tem (risos)". (P3)

É evidente que a condição de excepcionalidade faz com que estes pais tenham uma dedicação maior com os filhos (HENN; PICCININI, 2010), o que revela uma boa adaptação ao exercício da paternidade e adaptação ao filho. Para Chacon, (2011) a disponibilidade emocional para atender à demanda manifesta pelos filhos evidencia o grau de envolvimento paterno.

Os pais relatam cansaço físico e mental, vivências depressivas e estresse contínuo.

“[...] eu não tomo remédio, eu tenho a minha vida saudável, embora um desgaste físico, um pouco mental, estresse que todo mundo tem eu passo uma superação eu tenho um ponto principal para cuidar. [...] Não relaxa nunca né?" (P1)

"de vez em quando eu fico, eu me abato, sabe, eu fico para baixo, como eu vou te explicar como eu fico, mas assim é coisa de momento, dali a pouco tal eu já tô de novo tal, [...] quando eu sinto que ele tá meio mal e aí eu me 
derrubo, eu fico para baixo, baixo astral, mas eu que tenho que pegar ele, tenho que pôr, levar o outro e você já (risos) já foi e você nem teve tempo de pensar o quê". (P3)

"A gente fica triste de ver (pausa) não tem com quem desabafar (pausa)". (P7)

“Gostaria de ser mais forte, mas eu não consigo, eu não consigo, [...] nunca ninguém se preocupou em entrevistar os pais, sempre as mães, a minha esposa participa de trabalho lá em grupo, faz não sei o quê, não sei o que lá, mas os pais, ninguém". (P5)

Apesar de não referirem verbalmente que se sentem cansados pela rotina de cuidados imposta pela doença, percebe-se a sobrecarga vivenciada por eles quando relatam desgaste físico e mental, preocupação constante, sofrimento e tristeza. Os estudos de Chen (2008), Rosset (2009), Panganiban-Colares e Medina (2011), Pontes-Fernandes e Petean (2011), Pangalila et al. (2012) mostram que os pais e/ou cuidadores de crianças com doenças crônicas que afetam o desenvolvimento dos filhos e, muitas vezes, são letais, sentem-se sobrecarregados seja física e/ou emocionalmente. Pode-se supor que a sobrecarga emocional experimentada pelos pais deste estudo esteja relacionada ao tempo de convivência com a doença e consequentemente com as diversas perdas que os filhos apresentam como não conseguirem se alimentar sozinhos, higienizar-se, de se locomoverem mesmo sendo em cadeiras de roda motorizadas, ou até mesmo de se moverem no leito, estando assim totalmente dependentes de cuidados e até mesmo de aparelhos.

\subsection{A paternidade}

Aqui se discutirão os aspectos relacionados aos sentimentos despertados pela paternidade; as expectativas diante da possibilidade de ser 
pai; a paternidade específica em relação a uma criança do gênero masculino e as expectativas geradas por essa gestação: o companheirismo e a perpetuação da linhagem; a função identitária e a função social da paternidade; a função de provedor de sustento, de promotor de educação e formação moral e espiritual; a consequente oportunidade de crescimento pessoal advinda com a paternidade; o comportamento mais participativo e o padrão menos tradicional de paternidade, mais contemporâneo, em contraste com o modelo tradicional; o impacto positivo da paternidade de um filho excepcional sobre o desenvolvimento dos pais; a importância de os pais se manterem fortes diante da adversidade, mesmo se sentindo fracos, para dar bom exemplo aos familiares, dentre outras discussões.

A maioria dos pais verbalizou sentimentos de satisfação sobre a paternidade.

“[...] quando a gente era jovem, antes do meu primeiro casamento, a gente sempre quis casar e ter filhos, a ordem natural das coisas....Eu sempre quis, né, seguir a ordem natural das coisas, sempre quis ter filhos [...] eu gosto". (P2)

"sempre quis ter um filho, era um sonho meu". (P8)

A paternidade de uma criança do sexo masculino foi relatada pelos pais como muito especial e desejada.

"Feliz quando eu fiquei sabendo que era homem [...] tá nascendo um homem, você imagina ele, você começa a criar sonhos impossíveis, quase, não, não tão impossível [...] porque quando eu imaginei que fosse homem, seria um companheiro".(P1)

"A gente não sabia no começo (da gravidez), fomos saber só mais no final que seria um menino. Foi uma alegria total até para a família porque eles não tinham nenhum menino e minha irmã também só tem meninas. E minhas filhas mais velhas queriam um irmão. Foi muito gostoso, prazeroso, saber que eu teria um menino. Fiquei muito contente". (P2) 
“Olha, eu gostava de futebol, eu queria que fosse um jogador também, (risos) era ter um filho homem, como todo homem deve, pensa, né?". (P3)

“É o que eu imaginava, é o que um pai imagina. Jogar bola com o pai, paquerar, é isso". (P5)

"Ia nascer um homem, ia ser meu companheirinho". (P8)

Os relatos mostram a expectativa dos pais quanto ao nascimento de um homem, pois esperam que os garotos sejam seus companheiros, "jogadores de futebol" e que constituam família, perpetuando assim sua linhagem, demonstrando a satisfação com a paternidade e, em especial, com o fato de serem filhos do sexo masculino Revelaram os sentimentos em relação à paternidade, desde as expectativas sobre ser pai, o filho homem e como dão o significado à paternidade. Este significado acaba por determinar como o pai exerce a paternidade, como contribui para a adaptação da família à doença. De acordo com Krob e Piccinini (2009), mesmo quando a paternidade não foi planejada, sentem satisfação e prazer em serem pais.

Para um único pai deste estudo, tornar-se pai possui uma função identitária.

“O homem vira homem quando ele é pai, porque enquanto ele não é pai, ele é ainda um solteiro, independente, que a hora que tem o filho acaba a vida, a vida toda se pensa, tem coisa para amanhã, é tudo para hora, meu pensamento sempre foi esse, então quando pai é pai, não tem amanhã eu vou fazer, amanhã, não, é na hora tem que resolver o problema, [ ...]". (P3)

Para outros, a paternidade tem uma função social, com um papel bem definido. 
“Primeiro é prover o sustento do lar, né? Essa é primordial. Agora, ao contrário do que os outros falam, eu acho que o pai, é aquele que tem mais que colaborar na família, tanto para o crescimento dos filhos, para um bom relacionamento com a esposa, e ele tem que ser uma coisa que nós pregamos muito na igreja, ele tem que ser o exemplo da família, o exemplo. Em todos os sentidos". (P4)

“Eu acho que todo homem pensa assim, eu não posso ser diferente, a responsabilidade, na educação, na formação, hã, no sustento, né? [...] (a função do pai) Ah, ela é cinquenta por cento da história, tando interagindo, a função dele é estar procurando conviver, ele tem que participar de toda a história da família, do filho, conviver com isso e dar todo o suporte, seja financeiro, seja espiritual, seja afetivo, acho que a participação dele é constante, eu pratico isso, entendeu, eu nunca me ausentei". (P1)

Os relatos enfatizam o quão significativa é a paternidade para estes pais que mostraram perceber que são inerentes a este papel as funções de prover o sustento, promover a educação e formação em várias dimensões, da educação formal à espiritual e a participação ativa nos relacionamentos e no lar.

Neste estudo, os pais revelaram que, quando participam dos cuidados e estão mais presentes, sentem-se mais gratificados e contribuindo para a adaptação da família à doença, ao mesmo tempo que se sentem culpados quando não conseguem atender ao que consideram ser a função paterna.

“[...] a minha contribuição é a aceitação, ela não é passiva, mas eu não disse que eu não aceito, eu contribuo dessa forma, eu formalizo dessa forma que tinha que acontecer, que alguém tinha que fazer alguma coisa pela distrofia, é o que a gente tá fazendo então com a minha aceitação, hoje assim, nunca me revoltei $[\ldots] "$. (P1)

"acho que eu sou a pessoa que mais contribui para isso, porque eu tenho que ser o braço forte, as pernas dele, eu tenho que ser o psicólogo da casa, eu 
tenho que ser aquele que tem que mostrar antes, que tem que levar o sustento, eu, eu tenho que mostrar coragem, sabe? Eu sou o último a desabar, porque se, como é que você vai desabar se é você que tá segurando?". (P4)

A paternidade de um filho especial foi considerada como oportunidade de crescimento pessoal, de serem escolhidos por Deus, de serem "pais especiais".

“[...] eu acho que fui escolhido, eu tenho uma função para alguém especial, eu não devo de ser ausente e estou sempre presente e me sinto hoje, eu me sinto feliz, hoje, por ter um filho assim, porque faz crescer muito, entendeu? Faz crescer muito, então ser pai de uma criança especial você passa por muitas atribulações, mas quando você atinge uma etapa maior, você vê que aquilo foi um presente de Deus para você; por causa do Marcelo, muita coisa melhorou na minha vida $[\ldots] "$.. (P1)

Os relatos dos pais sobre suas concepções de paternidade demonstraram que, para alguns deles, a transição para a paternidade foi um momento de reelaboração da identidade masculina. De acordo com Teykal (2007), duas dimensões da identidade são reformuladas ao tornarse pai: a dimensão física, de ser capaz de gerar um filho e a parte moral, de ser capaz de sustentá-lo e educá-lo. As diferentes responsabilidades com o sustento do lar, com a participação na educação e formação, seja esta de caráter educacional, moral ou espiritual ficaram visíveis nestas falas e vêm permeadas pelos seus valores pessoais, culturais e religiosos. Estes resultados estão em consonância com os encontrados nos estudos de Brasileiro et al. (2010) e Krob e Piccinini (2009).

A participação direta nos cuidados com o filho e na divisão de tarefas domésticas é um comportamento expresso por estes pais, que exibem o exercício de uma paternidade menos tradicional, num padrão reconhecidamente mais participativo e afetivo, revelando um modelo de paternidade contemporânea, como descrito por Ceverny e Chaves (2010) 
e contrastando com os resultados de Freitas et al. (2009) que concluem que, no Brasil, os pais exercem um modelo mais tradicional de paternidade. Revela-se também a exigência de encarar todos os desafios, sem refutar a luta, tipificando o comportamento esperado para o gênero masculino, como descrevem Bruschini e Ricoldi (2012) e Nolasko (1995).

Outro ponto salientado pelos pais deste estudo é que a paternidade em si foi vista como oportunidade de crescimento pessoal, pois, de acordo com eles, tornaram-se mais responsáveis e amadurecidos após a experiência de ser pai. Estes resultados também foram encontrados no estudo de Lemay et al. (2010), nos quais os jovens pais associaram à paternidade mudanças comportamentais que consideraram positivas como assumir mais responsabilidades e encarar o próprio amadurecimento.

A paternidade na presença da excepcionalidade do filho, o modo de uma função paterna mais participativa ficaram bem caracterizados pelos pais deste estudo crianças. Nunes et al. (2008), no entanto, encontraram que os pais de especiais percebiam como função principal o provimento do sustento, ficando os cuidados com o filho a cargo materno, contrastando com o resultado encontrado nesse estudo em questão.

A função do provedor é muito importante, mas, não garante a satisfação com o papel paterno. A pouca disponibilidade paterna para a participação da vida familiar mostrou-se negativamente relacionada com o exercício almejado da paternidade, gerando frustração e sentimento de culpa nos pais que participaram deste estudo. Estes mesmos resultados foram encontrados por Henn e Piccinini (2010) e Teykal (2007). Em contrapartida, os pais que se percebem mais participativos nos cuidados com o filho e a família sentem-se mais gratificados e satisfeitos com a função paterna, relatando que contribuem com a adaptação da família à doença.

Pangalila et al. (2012) estudaram pais de adultos com DMD e estes demonstraram que, apesar da sobrecarga sentida por eles, consideram que cuidar do filho é importante e gratificante.

A paternidade de um filho excepcional também foi considerada um fator que impulsionou o desenvolvimento do pai como pessoa, fazendo-o 
tornar-se melhor, mais amadurecido, e, consequemente, adquirindo mais recursos internos após a vivência das muitas atribulações inerentes a esta condição. Ou seja, ser pai de um filho excepcional mostrou ser um fator que exerceu impacto positivo sobre o desenvolvimento pessoal dos pais, como retratado por Povee et al. (2012), que estudaram o funcionamento de famílias com crianças com síndrome de Down.

Os pais falaram sobre a importância de manterem-se fortes diante da adversidade, para dar bom exemplo aos familiares, muito embora percebam que fraquejam em alguns momentos mas, que isto não pode ser revelado à família.

"Eu nunca demonstrei fraqueza diante deles, eu nunca fiquei... sabe, às vezes, eu tava chorando, "Por que você tá chorando?" - "Eu briguei com a sua mãe"; eu nunca falava. Eu falo, "Como é que é? Vamos levantar daí?". Sempre dando aquela força". (P4)

A ideia de não poder demonstrar fraqueza diante das dificuldades diz respeito às atribuições usuais de gênero e com a figura do pai patriarcal e o estereótipo do masculino latino (NOLASCO, 1995, FREITAS et al., 2009; MOREIRA et al., 2010); porém, há que se refletir sobre os prejuízos que sofrem os homens ao se conformarem com essas atribuições: não poder demonstrar fraqueza, não poder demonstrar os sentimentos, não poder ter uma relação próxima com os filhos.

\subsection{Relacionamentos}

Na presente discussão, apresenta-se o que foi observado a respeito dos relacionamentos entre pai e filho, pai e mãe, pai e comunidade. No relacionamento pai/filho, a questão do companheirismo ficou bastante acentuada no relato dos pais, diante da paternidade de um filho homem; 
o companheirismo é visto pelos pais como oportunidade de um relacionamento aberto, atencioso e responsivo. Discute-se também a respeito da necessidade que os pais sentem em não esmorecer diante das dificuldades, pois estes se percebem como fonte de exemplo para os filhos. Quanto à relação pai/mãe, ou seja, a relação do casal, observou-se que a existência da doença mudou o relacionamento conjugal de alguns casais, segundo a percepção paterna, havendo relatos de afastamento, conflitos e dificuldades para se relacionar com as companheiras. Porém, como se poderá observar em seguida, a doença parece ter aproximado ainda mais um casal, segundo o relato de um pai participante da pesquisa. Serão também discutidas: algumas perturbações sentidas pelos cuidadores primários de pessoas com DMD, tais como dificuldades em satisfazer suas próprias necessidades, manter sua qualidade de vida, tendência ao isolamento social, que podem exercer impacto negativo sobre o seu ajustamento emocional, e resultar em níveis aumentados de stress e depressão; as mudanças sofridas em relação a outros membros da família, em decorrência do quadro clínico do filho; a questão da afetação pela doença, dos irmãos da criança vitimizada, já que os pais relatam haver diferenças na disponibilidade de cuidados entre o filho doente e os irmãos; por fim, será abordada a questão do relacionamento do pai com a família estendida e com a sociedade, ora propiciando aproximação, ora propiciando afastamento nas relações sociais.

Sobre o relacionamento pai e filho, o companheirismo foi relatado por todos os pais diante do fato de ser o filho um homem, que os faz compartilhar assuntos de interesse do gênero masculino.

“fiz questão também no que pudesse, ficasse junto, por ser homem, ele gosta muito de automóvel, ele sabe mais de automóvel do que eu, pela internet, por tudo, sabe? [...] porque o filho nessa situação vê o pai impotente, vai junto, a gente passa a ser o espelho do doente né? Quando você chega bem para o doente, você levanta o doente, quando você chega mal você acaba derrubando o doente, eu procurava, fazia todos os esforços 
para chegar bem em casa, mas com o cansaço no fim sempre escapava alguma coisa $[\ldots] " .(P 1)$

"eu sou o braço, eu sou a perna, eu sou amigo, eu sou pai, eu sou companheiro, eu sou tudo para ele, eu sou a expectativa dele sair de casa, eu sou o cara que ele sonha tudo, ele me cobra mais do que nunca. [...] tudo ele olha pra mim e pede pra mim, eu sou a fonte de todos os pro.., para resolver todos os problemas dele. [...] Quando ele andava, você pegava ele pela mão e saía andando, agora eu não posso pegar mais pela mão, eu empurro a cadeira, mas nós não deixamos de fazer nada do que a gente fazia". (P4)

“Mas eu vou montar a minha casa (de carnes), [...] Você sabe por quê? (Pausa) Por causa dele. [...] Para ficar comigo. (pausa seguida de choro)". (P5)

Os pais, em sua maioria, revelaram a dimensão do companheirismo entre pais e filhos, que Ihes permite manter um relacionamento aberto, atencioso e responsivo. Relataram a necessidade que sentem em não esmorecer diante das dificuldades, percebendo-se como fonte de exemplo para os filhos. Teykal (2007), em seu estudo sobre a paternidade, também encontrou que os pais acreditam que devem ser exemplos para os filhos.

Os pais se veem como fonte de soluções e de satisfação para todas as necessidades dos filhos e demonstram que se adaptam às novas exigências que aparecem em consequência das perdas relativas à doença. É provável que em decorrência da dependência que o quadro clínico acarreta, a relação entre o pai e o filho assuma uma importância maior, em que a função do pai vai além da função de provedor, levando-o a se tornar o cuidador secundário, auxiliando a mãe nos cuidados de higiene e alimentação.

A existência da doença na família mudou o relacionamento conjugal de alguns casais, segundo a percepção paterna. Eles relataram afastamento da relação conjugal, conflitos e dificuldades para se relacionar com as companheiras. 
"A nossa vida conjugal começou a ser, eu, ela e o Marcelo (risos) [...] e na parte de a nossa vida conjugal, ficou direcionada inteiramente ao problema do Marcelo [...] se você perguntar assim, atrapalha um pouco a vida conjugal? Claro, claro que atrapalha, porque, a Elizabeth, a gente não dorme juntos faz muitos anos, ela dorme no quarto com ele, mas porque ele precisa de atendimento e eu preciso ir para o trabalho e às vezes ... um pouco e isso aí .. um pouco a vida conjugal.... É claro que esfria, porque a gente se dividiu e doou essa parte por uma razão, não que isso terminou, mas é um entendimento profundo entre eu e ela". (P1)

"Afetou a minha relação com a Marina porque a carga dela ficou muito grande, a carga de trabalho ficou muito grande. Então, no relacionamento não brigamos, não fazemos... É porque a coisa começou a... O foco passou a ser outro: ao invés de eu e ela, hoje é ele e o resto [...] Na realidade acabamos nos afastando um pouquinho porque ela... Então, temos dificuldades sexuais. Na maioria das vezes não conseguimos manter relações. A coisa ficou um pouquinho perdida. Já faz um pouco de tempo que não conseguimos... Essa parte (sexual) não conseguimos ainda encaixar". (P2)

"Ah, várias mudanças, tem vez que a gente, sabe, tem vez que a gente discute, sabe, e tem vez que a gente fica até de mal, eu sei que... né, não é certo, por causo $[\ldots]$ Tem vez que você tá legal com ela, tem vez que tá de boa, tem vez que não,.... Assim, mudou muito". (P6)

“A gente era mais junto antes, agora não sei, às vezes a gente tá bem, mas ela tá sempre cansada. [...] Não falo que também não fico cansado, mas a gente é homem, né. Ainda não conseguimos acertar isso". (P8)

Mas houve relato de aproximação na relação conjugal, apesar da doença.

“A gente é muito unido [...] Eu gosto de fazer surpresa para ela, é diferente. Chegar com um buquê de flor, né? Que hoje é raro, escrever um cartão, que hoje ninguém gosta que é antiquado, fazer verso. Então, eu gosto de, ela 
gosta de chocolate, eu chego com uma barra de chocolate, e esse tipo de coisa que eu faço para ela". (P4)

Em decorrência da doença e sua progressão, os pais relataram que houve mudanças no relacionamento conjugal, mudanças estas que afetaram a convivência do casal e seu relacionamento sexual.

Estudos de Regen et al. (1993), Murata e Petean (2000), Nunes, Silva e Aiello (2008), Nascimento et al. (2009), Kohlsdorf e Costa (2012) e Povee et al. (2012), apontam para o fato de que as relações parentais na presença de doenças crônicas se modificam. As exigências diárias de cuidados, a sobrecarga que a enfermidade acarreta foram as explicações dadas pelos pais para justificar as mudanças percebidas na vida do casal. De acordo com Poysky (2008) perturbações significativas são sentidas pelos cuidadores primários de pessoas com DMD, como dificuldades em satisfazer suas próprias necessidades, manter sua qualidade de vida, tendência ao isolamento social, fatores que podem exercer impacto negativo sobre o seu ajustamento emocional, e resultar em níveis aumentados de stress e depressão. Nascimento et al. (2009) destacam que tanto apatia ou desinteresse sexual, intensificação dos conflitos relacionais, ou mesmo separação do casal podem ser resultantes da presença do câncer infantil.

Os relatos mostram que as relações com os outros membros da família também sofreram mudanças em decorrência do quadro clínico do filho.

“[...] eu acho que a (irmã) ficou um pouco penalizada assim, mais pelo atendimento que teve porque a gente direcionou, focou, claro depois a gente entendeu, mesmo com as suas reservas de afetividade". (P1)

"Minha filha volta da escola, e como a Marina fica em casa de manhã e sai com o Henrique para fazer as coisas, a menina chega em casa e não tem ninguém [...] porque ela sente, não é que ela sente que a gente está preterindo... mas ela também precisa de carinho, que, na realidade, a gente 
não pode estar dando o tempo todo. Ela, às vezes, entende. [...] A divisão de carinho não é proporcional. Aliás, não é do carinho, é do cuidado". (P2)

Pelos relatos, pode-se constatar que, quando há irmãos, estes, na percepção dos pais, são os que mais foram afetados. Os pais percebem diferenças na disponibilidade de cuidados entre o filho doente e os irmãos. Para Chacon (2011), os pais podem perceber que tendem a centralizar os cuidados no filho doente, em detrimento dos outros filhos. Petean e Siguihura (2005) e Nascimento et al. (2009) relatam que os irmãos podem experienciar, nestas circunstâncias, sentimentos de isolamento e abandono, bem como manifestar reações de ciúme, raiva, revolta, tristeza e irritação.

Referindo-se às relações com a família estendida e com a sociedade, alguns pais relatam que a DMD propiciou aproximação; outros consideram que houve afastamento nas relações sociais.

“[...] mas aqueles que vieram os amigos de freqüência de dentro de casa não vêm mais, aí eu expliquei para Elizabeth, e achei super interessante, mas é, a doença do Marcelo não é mais novidade para ninguém, ninguém mais, todo mundo entende que o Marcelo tá aí, tornou uma doença comum, mesmo da gravidade que é, mas o Marcelo tá aí, as pessoas não se importam, não que não se importam com a gente, alguns vêm sempre, os casais que estão acostumados a vir, vêm, perguntam, liga vem e tal, mas a maioria foi embora [...]". (P1)

"Tem uns amigos de faculdade com os quais me comunico, de vez em quando, pela internet. E todos eles me deram seus telefones e falaram que iriam procurar conseguir consulta com não-sei-quem. Todos passaram a dar uma atenção maior e se preocupar realmente com isso [...] Houve com os meus ex-cunhados e minha mãe. Então, o relacionamento, em função disso, acho que aumentou um pouco". (P2)

"não condeno nenhum dos irmãos que se afastaram, outros que se afastaram totalmente [...] de vez em quando eu sinto, a gente sente falta, lógico". (P3) 
"não tenho assim aquela vida social, em função. As pessoas começam a te, a ter uma certa reserva com você. $\mathrm{Na}$ verdade existe um grande preconceito com pessoas, sabe, quer queira ou quer não, você sofre um grande preconceito, a não ser o pessoal da igreja, que vai lá, mas você percebe que algumas pessoas se importam, tão ali, são seus amigos e outros já não". (P4)

"Agora, quando meu filho ficou doente, meus cunhados foram tudo lá, meu sogro foram lá, eles são meus amigos". (P5)

As mudanças nos relacionamentos sociais em consequência de uma doença crônica na família têm sido apontadas na literatura. O estudo de Kenneson e Bobo (2010) mostra que as mães de pessoas com distrofia muscular, de Becker ou Duchenne, vivenciam um retraimento social, autoimposto ou não e que está relacionado com uma maior dependência do filho, pelas exigências de cuidados maiores após a perda da deambulação. Dados semelhantes foram encontrados no trabalho de Pontes-Fernandes e Petean (2011), com mães de filhos que são diagnosticados com erros inatos do metabolismo.

Na presença da deficiência física, segundo Silva (2006) e Rigão et al. (2011), o afastamento social ocorre. A deficiência é vista como um fator em potencial para a emergência do preconceito, de acordo com Silva (2006), pois a presença de indivíduos com deficiência física/intelectual acentua a visão das diferenças em relação aos padrões de normalidade, remete à imperfeição humana, à falta e ausência de possibilidades, fazendo que as pessoas manifestem atitudes defensivas para evitar o sofrimento.

\subsection{0 luto}

Aqui se discutirá sobre o processo de luto, iniciado desde a percepção dos sintomas e confirmado pelo diagnóstico da doença. 
Apresentar-se-á o processo de luto antecipatório, ou seja, a visão antecipada da morte do filho diagnosticado com DMD e as implicações advindas desse luto. Apresentar-se-ão, ainda: a dificuldade dos pais ao lidar com as perdas funcionais ocorridas no curso da doença, em especial o momento da perda da capacidade de deambulação; o processo de elaboração dessas perdas e a gama de sentimentos por elas despertada; os desgastes provocados por um longo processo de luto em todos os que nele estão envolvidos; as expectativas frustradas pela ocorrência da doença, em relação ao futuro do pai e da família; os recursos exigidos pelo filho doente; as limitações trazidas pela doença e os sacrifícios praticados pelo pai diante de tais limitações; as modificações e adaptações ao estilo de vida, às expectativas pessoais, provocadas pela doença; o temor do pai, diante da possibilidade da própria morte e da morte da mãe, e o consequente temor de deixar o filho doente sem cuidados; por fim, serão discutidas a falta de sentido na vida dos pais e a perda do papel de cuidador, diante da iminência da morte do filho doente, em virtude do grande investimento de recursos físicos, afetivos e financeiros para mantê-los vivos.

A notícia do diagnóstico de uma doença crônica e/ou deficiência desencadeia um sentimento de perda do filho idealizado.

O relato dos pais mostrou o processo da perda do filho idealizado, do seu desenvolvimento normal, que se inicia com a percepção dos sintomas e se confirma pelo diagnóstico da doença.

“De ser uma criança normal, uma criança que corresse, jogasse bola, que brincasse. Eu jamais imaginei que eu ia ter um filho com uma doença degenerativa. Nunca me passou isso pela cabeça". (P4)

Uma doença crônica ou degenerativa como a DMD deflagra com seu diagnóstico o processo de luto antecipatório, pois os pais, cientes do curso da doença, já se veem perdendo as possibilidades de ver suas expectativas em relação ao desenvolvimento normal do filho se 
esvanecer. Antes mesmo da confirmação do diagnóstico, o desenvolvimento do filho já sinalizava para um atraso ou problema desenvolvimental, como citado anteriormente, que frustrou a expectativa da normalidade.

Os pais demonstraram a dificuldade em lidar com as perdas funcionais que acontecem no curso da doença, em especial o momento da perda da capacidade de deambulação.

“é muito feio quando eles começam a parar de andar, meu filho começou a andar de uma forma, é terrível, caía, rachava a cabeça, cortava o queixo, se arrebentava inteiro, anda igual um pato, parecia um pato, entendeu?". (P5)

"foi muito difícil para todo mundo aqui em casa entender que ele precisava da cadeira". (P8)

Conforme Rolland (1998) salientou, a cada marco da evolução da doença, confirmando o seu curso progressivo e letal, as famílias enfrentam o sofrimento antecipado diante das incapacidades e da morte iminente. O processo do luto antecipatório pode ocorrer durante um longo período, pois as perdas funcionais que acontecem progressivamente prejudicam as atividades que o doente executava anteriormente. Essas perdas carecem de elaboração seja por parte do doente seja por parte dos familiares, e despertam em todos uma gama de sentimentos dolorosos (FLACH et al., 2012). De acordo com Kovacs (2008), um processo longo de luto acarreta desgaste físico e psíquico nos que nele estão implicados.

Alguns pais falam das expectativas que foram frustradas pela presença da doença, relativas ao seu futuro e ao futuro da família. Projetos pessoais tiveram que ser abandonados em função da dedicação e dos recursos que o filho doente exige.

“projetos futuros, a Elizabeth, ela é professora, dava aula de artesanato, ela tem conhecimento, habilidade muito forte, então ela trabalhava com 
artesanato isso para alicerçar o orçamento de casa que a gente tinha sonhos de ter uma casa melhor vamos colocar, busca de um amparo financeiro amanhã e ela sempre me ajudou muito nessa parte e tinha sonhos assim, era para vencer mas isso dentro de uma possibilidade possível, dentro de uma possibilidade. [...] mas eu já tinha sonhos de melhorar a situação financeira, um carrinho melhor, um segundo carro para Elizabeth, tá? [...] houve a compra do aparelho $[\ldots] "$.. (P1)

“Eu tocava violão, ou eu cantava, ultimamente nem isso eu não tenho feito mais, porque realmente não dá tempo, né?". (P4)

Um pai, logo após o diagnóstico, percebendo as limitações que a doença acarretaria, abandonou uma atividade de sua preferência.

“infelizmente, eu não vou mais poder tocar música com você; meu filho tem uma doença neurodegenerativa, ele vai precisar de mim e minha esposa vai precisar de mim, e foi aí que eu decidi" (tosse) Meu amigo continuou a vida dele, toca por aí, montou banda, e eu (tosse), eu tracei meu destino aí". (P5)

Os pais sentiram que a doença acarretou outras perdas em relação ao estilo de vida pessoal e da família.

"a gente sempre aproveitou muito a vida junto, a vida noturna a gente sempre foi, então, teve uma vida. Depois, logicamente, foi caindo então (risos) mas, quando eles começaram a depender realmente da gente, paramos com tudo, sem problema nenhum, sem que atrapalhasse, assim, que atrapalhasse não, que fizessem com que a gente tivesse vontade de ter algum, ter mais alguma coisa, a gente teve uma vida assim proveitosa, antes deles, depois deles a gente entendeu da situação, e passamos a viver só por conta deles". (P3)

A doença evidenciou-se como um marco na vida dos familiares que tiveram que promover modificações e adaptações ao estilo de vida, às expectativas pessoais. Rolland (2001), Dessen e Costa-Junior (2005), Camargo e Londero (2008) em estudos sobre deficiência e doença crônica, 
encontraram resultados semelhantes, ou seja, a doença crônica/deficiência exigiu mudanças no sistema familiar para adaptação à doença do filho, sendo um processo que pode durar tempo considerável e alterar o estilo de vida, valores e papéis.

Alguns pais falaram sobre a morte e relatam que temem não só a morte do filho, como a deles próprios e das mães.

"se eu tivesse numa situação amanhã ou depois que eu fosse embora ela não dá conta, se ela for embora, eu dou menos conta ainda, eu sou pai não sou mãe e por isso. O Marcelo vai embora, vai perder totalmente a consistência de vida e não vai querer viver mais, entendeu? [...] eu vou ver se ele tá vivo, a noite que ele não chama, embora hoje nós temos um aparelho que se acontecer alguma coisa o aparelho vai bipar, a gente tem toda a experiência disso daí, se morrer não vai chamar antes de utilizar o aparelho, ia ver se ele tava vivo ou não, isso para mim preparar a Elizabeth para aceitar isso, você entendeu?" (P1)

"quando eu penso se é melhor eu morrer antes ou eles morrer primeiro que eu, porque eu não sei como eu vou suportar se eles falecerem antes, não sei, como eu vou me reagir, e às vezes, eu prefiro ir antes, mas eu fico com medo de quem vai cuidar deles, então, é a única coisa, a única coisa que eu, às vezes, na minha cabeça vem nesse ponto, (risos) se eles vão primeiro ou se vou eu primeiro". (P3)

"Ver o filho morrer, que mãe que vai suportar ver o filho morrendo pouquinho a pouquinho. Sabendo que enquanto os outros filhos tão aí desenvolvendo, estudando, trabalhando, pensando em casar, o seu tá ali, sem expectativa de quê? Qual é a expectativa dele? O que que você espera para ele? Ele vai cada dia mais depender de você, degenerar mais, necessitar mais, e você vai ter que dar muito mais amor, entendeu? É isso que eu tô falando". (P5)

"eu tenho muito medo sabe, eu tenho muito medo da doença, de eu morrer eu ficar doente e não poder dar o melhor pra ele, que graças a Deus até hoje nunca deixei faltar nada, né". (P6) 
É doloroso para estes pais, assim como para qualquer pai, pensar na morte do filho. Neste caso em especial, a morte do filho chega lenta e inexoravelmente. Os pais participantes demonstraram estar conscientes das etapas esperadas da progressão da doença, e que, a cada involução que o filho apresenta, confirma-se a iminência da morte. É uma ruptura enorme no curso esperado da vida, que pressupõe a morte dos pais precedendo sempre a dos filhos. (FLACH et al. (2012)) e (MENEZES et al. (2007)).

O vínculo estreito estabelecido por estes pais com seus filhos, pela sua grande dependência de cuidados, faz os pais sentirem que a vida deles e das esposas ficará sem sentido, pois há um enorme investimento de recursos físicos, afetivos, financeiros para mantê-los vivos. De acordo com Cunha et al. (2011) a relação próxima entre cuidador e doente faz aumentar o vínculo entre eles durante o adoecimento. O cuidador percebe-se cada vez mais envolvido e responsável para atender às necessidades do doente, respondendo sempre prontamente para aliviar seu sofrimento e diminuir sentimentos de culpa em relação ao enfermo. Visto que a maior parte das atividades dos pais envolve o cuidado do filho, pensar em sua morte implicará também a perda do papel de cuidador. 
6 CONCLUSÕES 

Ao finalizar, fazem-se necessárias algumas considerações sobre os dados aqui apresentados. Não se pode considerar a pesquisa na área como concluída; há muito a ser trabalhado e aprofundado, inúmeras possibilidades de investigação e de caminhos a serem trilhados na busca de se compreender os significados e implicações de "ser pai de um filho com diagnóstico de doença crônica".

Inicialmente, é necessário ressaltar a adequação do método utilizado, que se mostrou pertinente aos objetivos dos estudos propostos e que permitiu à pesquisadora obter um tipo de dado rico e impossível de ser obtido através de outras estratégias.. O uso de roteiros de entrevistas estruturados com questões abertas mostrou-se eficiente e adequado, possibilitando que se obtivessem os mesmos dados para todos os sujeitos, respeitando a sequência narrativa de cada um deles, possibilitando a sistematização dos dados e o seu aprofundamento com a análise qualitativa. Além de possibilitar o acesso aos dados, o momento da entrevista foi visto pelos pais como uma oportunidade para exporem suas angústias e seus sentimentos, que muitas vezes não são compartilhados com a família e amigos. Embora os resultados obtidos sejam consistentes, não se pretende, com isto, afirmar que sejam passíveis de generalizações, visto que, tanto a paternidade quanto a presença de uma doença crônica na família envolvem vários aspectos biopsicossociais

É certo que determinados resultados destes estudos vieram confirmar o que já vinha sendo apresentado na literatura; e assim o é com relação à paternidade; os pais referiram satisfação com a nova condição, mostraram-se adaptados e vinculados aos seus filhos. A paternidade foi vista, por alguns deles, como um fator que impulsionou seu amadurecimento e crescimento pessoal, conferindo-lhes a confirmação da identidade masculina.

O fato de serem pais de filhos homens foi também motivo de satisfação, pois ao saberem que teriam filhos do sexo masculino, suas expectativas revelaram que esperavam companheirismo e que estes thes garantiriam a descendência. Essas expectativas foram frustradas em 
decorrência do diagnostico da doença degenerativa do filho, deflagrando o luto pelo filho idealizado.

Os pais revelaram suas concepções, valores e crenças a respeito de como exercer o papel paterno, que foi descrito como composto pelas dimensões de provedor, de fonte de educação, pela garantia da educação formal e como exemplo de moral. É preciso ressaltar que a doença crônica existente foi um fator que exigiu maior adaptação do pai no que concerne a cuidados, em virtude da maior dependência dos filhos, o que fez com que exercessem um padrão mais participativo nos relacionamentos, na educação e nos cuidados com os filhos. Estes resultados evidenciaram a construção de um modelo paterno que difere da paternidade tradicional, pois envolve mais a dimensão afetiva, uma maior proximidade e disponibilidade nos relacionamentos e na participação da vida familiar. Os pais que, em virtude de sua ocupação profissional, não conseguiram atender a este novo modelo almejado de paternidade, sentiram-se menos gratificados, percebendo-se culpados por não exercê-lo.

A paternidade de um filho com deficiência foi percebida por eles como um fator que os fez sentirem-se "pais especiais", promovendo também amadurecimento e crescimento pessoais. Os pais atribuíram à paternidade o significado de missão a ser cumprida e este significado foi permeado pelo sistema de crenças e valores religiosos. O significado dado à "paternidade especial" influenciou positivamente na adaptação à doença, pois favoreceu a elaboração psíquica, mantendo-os motivados frente à adversidade.

Os resultados mostraram que, mesmo antes do diagnóstico da DMD, alguns pais vivenciaram a frustração de perceberem que os filhos não estavam se desenvolvendo dentro dos padrões da normalidade. Após a confirmação do diagnóstico, pode-se verificar, em seus relatos, a vivência de alguns sentimentos comuns a todos eles como a reação de choque e sentimentos de desespero, impotência e até mesmo o desejo de morrer. $O$ momento da notícia foi vivido com muita dor, carregado de emoções e sentimentos fortes, e que, em alguns pais, fez emergir defesas como a 
negação, que sabidamente complicam a assimilação da notícia, e acarretaram iniciativas equivocadas na busca da cura ou melhora do filho.

O conhecimento do diagnóstico, bem como as informações recebidas não foram suficientes para gerar um significado da doença que aplacasse a dor psíquica destes pais; assim, eles recorreram ao seu sistema de valores e crenças, para encontrar o significado da doença dos filhos. As crenças religiosas influenciaram no modo como os pais perceberam a enfermidade, fornecendo-Ihes uma explicação para que pudessem lidar com o sofrimento de ter um filho acometido por uma doença grave, degenerativa, com um prognóstico de vida até os 20 anos de idade, ou seja, uma doença letal. Fica claro que a maneira como os pais vão agir tem uma ligação direta com o significado que a DMD tem para eles, seus preconceitos, valores morais e religiosos.

Neste sentido, cabe ressaltar que os profissionais médicos, ao diagnosticarem um menino com DMD, devem estar sensibilizados quanto às implicações deste diagnóstico para os pais e para a família, promovendo um espaço de acolhimento e facilitando a elaboração da notícia. O ideal seria que pudessem receber apoio psicológico desde este momento, auxiliando-os na elaboração do processo de luto antecipatório que se instala desde então.

Considera-se que seja de grande ajuda para estes pais, no momento do diagnóstico, que os profissionais de saúde envolvidos possam adotar condutas mais humanizadas, acolhendo-os em sua dor, fornecendo as informações de maneira clara e simplificada e verificando se esta foi bem compreendida, para benefícios dos pais e das crianças. Salienta-se ainda a necessidade de respeitá-los em sua fé que, neste estudo, mostrou-se como um fator associado positivamente para a elaboração do significado da doença e dos recursos utilizados para o enfrentamento.

Dentre os recursos utilizados pelos pais para enfrentarem a doença dos filhos, a busca ativa de informações e recursos para adaptação à doença, o apoio da rede social e a religiosidade foram os mais relatados. Os pais demonstraram estarem atentos às necessidades dos filhos, 
conscientes das implicações do quadro clínico, informando-se sobre novos tratamentos. Alguns pais ainda relataram o desejo de que ocorresse uma cura milagrosa; entretanto, isto não se apresentou como um impedimento para que eles propiciassem o atendimento necessário ao filho ou mesmo como algo que interferisse no enfrentamento efetivo da doença. A religiosidade mostrou-se como um apoio importante e como redutor de estresse para estes pais, que recorreram a ela quando se sentiram abatidos, nos momentos de dor e desesperança, ajudando-os a suportar a pesada carga imposta pela doença.

Os pais suportam uma significativa sobrecarga física e psíquica por causa da doença. São muitos os estressores a que estão expostos: relataram desgaste físico e mental, preocupação constante, sofrimento e tristeza. No cotidiano, mostraram disponibilidade para as questões afetivas dos filhos, procuraram envolver-se diretamente na rotina de cuidados com eles, preocupando-se com a alimentação, higiene, lazer, educação. Empreenderam esforços para garantir os equipamentos necessários à melhoria da qualidade de vida dos filhos e alguns perceberam-se como cuidadores secundários, procurando aliviar a carga das mães, a quem competia a responsabilidade dos cuidados. A preocupação com os recursos financeiros esteve presente, pois além do sustento da família, tiveram que se programar para adquirir os aparelhos, como cadeiras de rodas, respiradouros etc, necessários à manutenção da "saúde", ou melhor, da qualidade de vida dos filhos.

No tocante a relacionamentos, este estudo mostrou, em concordância com a literatura, que a presença de uma doença crônica na família afeta as relações interpessoais. O relacionamento pai e filho foi percebido como próximo, aberto e afetivo pela maioria dos pais, assim como o fato de o filho ser do sexo masculino, o desejo e a expectativa do companheirismo mostraram-se presentes no relacionamento dos pais deste estudo. Apesar de não ter sido explicitado por eles, é possível supor que a presença da doença, da deficiência física que acarreta, do grau elevado de dependência dos filhos, fez os pais tornarem-se mais 
companheiros e mais atenciosos neste relacionamento.

Mudanças no relacionamento conjugal em decorrência da doença foram relatadas pelos pais. Alguns sentiram um afastamento na relação do casal e problemas no ajustamento sexual e atribuíram esta mudança à importante sobrecarga que as mães experimentam e somente um pai relatou que houve aproximação do casal. Sabidamente, a presença da doença crônica afeta os relacionamentos, exercendo uma força centrípeta ou centrífuga no sistema familiar e, assim como em outros estudos, os resultados aqui obtidos demonstram que não há um padrão; tanto ocorre de o casal se unir mais e trabalhar em torno do cuidado e promoção do desenvolvimento do filho, quanto de se distanciar.

O relacionamento com os outros filhos, com a família e a comunidade também sofreu alterações. Alguns pais relataram afastamento e outros aproximação nos relacionamentos interpessoais. Em relação aos outros filhos, eles percebem que dispensam mais cuidados aos filhos doentes e que os irmãos se ressentem disso e um pai revelou que percebe o preconceito das pessoas que resulta, de acordo com ele, no afastamento dos amigos e da comunidade.

O processo de luto foi desencadeado, para alguns, quando perceberam precocemente que o filho não se desenvolvia como o esperado e, para outros, quando os sintomas da DMD tornaram-se mais evidentes e, posteriormente, com a confirmação do diagnóstico. A princípio, os pais mostraram o sofrimento advindo da perda do filho imaginado/idealizado, para então vivenciarem um luto antecipatório que se intensifica a cada involução no quadro clínico. Este processo expõe os pais a uma gama de sentimentos dolorosos, que os atinge física e psiquicamente, exigindo-Ihes elaborações constantes. Pensar e falar sobre a morte, para estes pais, foi muito difícil, pois além do temor da morte do filho, temem que uma doença ou a morte possa atingi-los ou à mãe, ficando o filho dependente de cuidados sem assistência.

É importante frisar que estes pais e suas famílias vivenciam um processo de luto antecipatório, que se assevera com as sobrecargas física 
e emocional advindas do adoecimento do filho, com as mudanças nas relações interpessoais, as demandas de recursos financeiros e de apoio/suporte social. É sabido que a presença da doença crônica é um fator de risco significativo para a saúde mental dos pais, expondo-os aos mais altos níveis de estresse e vivências depressivas, justificando a necessidade de maior atenção à saúde destas famílias. Neste estudo, foi manifestada pelos pais a necessidade de um espaço para que possam falar sobre seus sentimentos, já que estes não podem ser expressos perante a família, em virtude de julgarem que, como patriarcas que são, devem se mostrar inabaláveis e fortes para auxiliar na adaptação da família à doença. Ao proporcionar aos pais uma oportunidade de verbalizar sua história, suas angústias, pode-se perceber o quão difícil para eles é suportar a carga emocional que não pode ser compartilhada com os familiares.

Fica claro, portanto, que os resultados dos estudos realizados não só trouxeram informações e confirmações importantes, como também abriram o caminho para novas explorações, objetivando conhecer as implicações da paternidade de um filho com doença crônica e os fatores psicossociais nela envolvidos.

É necessário considerar que a leitura dos dados e a interpretação dos resultados são fundamentadas na opção teórica da pesquisadora e que, portanto, refletem suas crenças. 
REFERÊNCI AS 

AUN, J. G., ESTEVES DE VASCONCELLOS, M. J.; COELHO, S.V. (2005). Atendimento de famílias e redes sociais: Fundamentos teóricos e epistemológicos. Belo Horizonte: Ophicina da Arte \& Prosa.

BALANCHO, L.S.F. (2004). Ser pai: Tansformações intergeracionais na paternidade. Análise Psicológica, 2 (XXII): pp. 377-386.

BARBONI, M. T. S. (2012). Avaliação eletrofisiológica e psicofísica das vias visuais ON e OFF em jovens com distrofia muscular de Duchenne. Tese de Doutorado, Instituto de Psicologia, Universidade de São Paulo, São Paulo. Recuperado em 2013-01-17, de http:// www.teses.usp.br/teses/disponiveis/47/47135/tde-10052012-143831/

BELTRÃO, M.R.L.R, VASCONCELOS, M.G.L., PONTES, C.M., ALBUQUERQUE, M.C. (2007). Câncer infantil: percepções maternas e estratégias de enfrentamento frente ao diagnóstico. Jornal de Pediatria, 83 (6), 562-566.

BIASOLI-ALVES, Z. M. M. (1998). A pesquisa psicológica: análise de métodos e estratégias na construção de um conhecimento que se pretende científico. In: ROMANELLI, G; BIASOLI-ALVES, Z. M. M. (Org.). Diálogos metodológicos sobre prática de pesquisa. Ribeirão Preto: Legis Summus, $176 \mathrm{p}$.

BLEGER, J. Temas de psicologia: entrevistas e grupos. 2.ed. São Paulo: Martins Fontes, 1998.

BRADT, J.O. Tornando-se pais: famílias com filhos pequenos. In: CARTER, B.; MCGOLDRICK, M. (2001). As mudanças no ciclo de vida familiar: uma estrutura para a terapia familiar. Trad. Maria Adriana Veríssimo Veronese. 2.ed. 2.Reimpressão. Porto Alegre: Artes Médicas.

BRASILEIRO, P.G.L., PONTES, V.V., BICHARA, I.D., BASTOS, A.C.S. (2010). A transição para a paternidade e a paternidade em transição. IN: MOREIRA, L.V.C., PETRINI, G., BARBOSA, F.B. (Org.) (2010). O pai na sociedade contemporânea. Bauru-SP: EdusC.

BRUNHARA, F.; PETEAN, E.B.L. Mães e filhos especiais: reações, sentimentos e explicações à deficiência da criança. In: Paidéia Cadernos de Psicologia e Educação da Faculdade de Filosofia, Ciências e Letras de Ribeirão Preto - USP. № 9(16):31-4014/15 jan.-jul. 1999. 
BRUSCHINI, M.C.A., RICOLDI, M.A. (2008). Revendo estereótipos: o papel dos homens no trabalho doméstico. Estudos Feministas, Florianópolis, 20(1), 259-287.

BUSCAGLIA, L. Os deficientes e seus pais: um desafio ao aconselhamento. Rio de J aneiro: Record, 1993.

CAMARGO, S.P.H, LONDERO, A.D. (2008). I mplicações do Diagnóstico na Aceitação da Criança com Deficiência: Um Estudo Qualitativo. Interação em Psicologia, 12(2), 277-289.

CARTER, B.; MCGOLDRICK, M. (2001). As mudanças no ciclo de vida familiar: uma estrutura para a terapia familiar. Trad. Maria Adriana Veríssimo Veronese. 2.ed. 2.Reimpressão. Porto Alegre: Artes Médicas.

CARVALHO DE SOUZA, C.L.; BENETTI, S.P.C. (2008). Paternidade e desemprego: características do envolvimento paterno e aspectos do relacionamento familiar. Contextos Clínicos, 1(2), 61-71.

CEVERNY, C.M.O., CHAVES, U.H. (2010). Pai? Quem é este? A vivência da paternidade no novo milênio. IN: MOREIRA, L.V.C., PETRINI, G., BARBOSA, F.B. (Org.) (2010). O pai na sociedade contemporânea. Bauru-SP: Edusc.

CHACON, M.C.M. (2011). Aspectos relacionais, familiares e sociais da relação pai-filho com deficiência física. Rev. Bras. Ed. Esp., Marília, 17 (3), 441-458.

CHEN, J.Y. (2008). Mediators Affecting Family Function in Families of Children with Duchenne Muscular Dystrophy. The Kaohsiung J ournal of Medical Sciences, 24 (10), 514-522.

CHEN, J.Y.; CLARK, M.J. (2007). Family function in families of children with Duchenne Muscular Dystrophy. Family and Community Health, 30(4), 296-304.

CLARK, S.M.; MILES, M.S. (1999). Conflicting responses: the experiences of fathers of infants diagnosed with severe congenital heart disease. JSPN, 4(1) NO.1. 
CUNHA, D.M.F; FREITAS, L.B.; OLIVEIRA, M.S. (2011). Familiar cuidador de paciente com doença terminal frente ao processo de adoecimento. Trabalho de curso. Pontifícia Universidade Católica do Rio Grande do Sul, Disponível em: < http://www.psicologia.pt/artigos/ textos/TL0246.pdf>, Recuperado em 10 de jan. 2013.

CUNNIFF, A.L. (2012). Psychosocial adjustment, experiences and views of fathers of sons with Duchenne Muscular Dystrophy. Disponível em: <http://www.duchennefoundation.org.au/files/5s5n1586 cn/cunniff.pdf>. Acessado em: 20 de maio de 2012.

DAOUD, M.S.A; DOOLEY, J.M.; GORDON, K.E. (2004). Depression in parents of children with Duchenne Muscular Dystrophy. Pediatric Neurology, v. 31, n.1, p.16-19.

DESSEN, M. A.; BRAZ, M. P. (2000). Rede social de apoio durante transições familiares decorrentes do nascimento de filhos. Psicologia: Teoria e Pesquisa, 16(3), 221-231.

DESSEN, M.A.; COSTA JUNIOR, A.L. et Col. (2005). A ciência do desenvolvimento humano: tendências atuais e perspectivas futuras. São Paulo: Artmed.

DESSEN, M.A; LEWIS, C. (1998). Como estudar a família e o pai? In: Paidéia - Cadernos de Psicologia e Educação da Faculdade de Filosofia, Ciências e Letras de Ribeirão Preto - USP. № 14/15 Fev/Ago 1998.

DUARTE, R. (2004). Entrevistas em pesquisas qualitativas. Educar. Curitiba: 2004, n.24, p.213-225.

ERBY, L.H.; RUSHTON, C.; GELLER, G. (2006). My son is still walking: Stages of receptivity to discussions of advance car planning among parents of sons with Duchenne Muscular Dystrophy. Seminars in Pediatric Neurology, 13, 132-140.

FIRTH, M. A. (1983). Diagnosis of Duchenne muscular dystrophy: experiences of parents of sufferers. BRITISH MEDICAL J OURNAL, 286, 700-7001.

FLACH, K., LOBO, B.O.M., POTTER, J.R., LIMA, N.S.(2012). O luto antecipatório na unidade de terapia intensiva pediátrica: relato de experiência. Rev. SBPH vol.15 no.1, Rio de Janeiro - Jan/jun, 83-100. 
FLEITH, D.S.; COSTA JUNIOR, A.L. (2005). Métodos de pesquisa em psicologia do desenvolvimento: o que é relevante considerar. In: DESSEN, M.A.; COSTA JUNIOR, A.L. et Col. A ciência do desenvolvimento humano: tendências atuais e perspectivas futuras. São Paulo: Artmed.

FONSECA, C. (2004). A certeza que pariu a dúvida: paternidade e DNA. Rev. Estud. Fem., Maio/Ago, 12 (2): 13-34.

FONSECA, J. P. (2004). Luto Antecipatório. Campinas: Editora Livro Pleno.

FREITAS, W.M.F.; SILVA, A.T.M.C.; COELHO, E.A.C.; GUEDES, R.N.; LUCENA, K.D.T; COSTA, A.P.T. (2009). Paternidade: responsabilidade social do homem no papel de provedor. Rev Saúde Pública v.43, n.1, p. 85-90.

GENESONI, L.; TALLADINI, M.A. (2009). Men's psychological transition to fatherhood: an analysis of the literature, 1989-2008. Birth, v.36, n.4, p.305-317.

GOES, F.A.B. (2006). Um encontro inesperado: os pais e seu filho com deficiência mental. Psicol. cienc. prof., Brasília, v. 26 , n. 3 , set. 2006. Disponível em <http://pepsic.bvsalud.org/scielo.php?script=sci_ arttext\&pid=S1414-98932006000300009\&lng=pt\&nrm=iso > . acessos em 10 set. 2012.

GOMES, A.J.S; RESENDE, V.R. (2004). O Pai Presente: o desvelar da paternidade em uma família contemporânea. Psicologia: Teoria e Pesquisa. Vol. 20 n. 2, pp. 119-125. Mai-Ago.

GONTIJO, D.T.; BECHARA, A.M.D.; MEDEIROS, M;ALVES, H.C. (2011). Pai é aquele que está sempre presente: significados atribuídos por adolescentes à experiência da paternidade.

HENN, C.G., PICCININI, C.A. (2010). A Experiência da Paternidade e o Envolvimento Paterno no Contexto da Síndrome de Down. Psicologia: Teoria e Pesquisa,. 26 (4), 623-631.

HENNIGEN, I.; GUARESCHI, N.M.F. (2002). A paternidade na contemporaneidade: um estudo de mídia sob a perspectiva dos estudos culturais. Psicologia \& Sociedade; v.14 (1): pp. 44-68; jan./jun. 
HODGES, L. (2010). Social Comparison within Self-help Groups: Views of Parents of Children with Duchenne Muscular Dystrophy. Journal of Health Psychology. 15(4), 483-492.

JAMES, C.A. et al. (2006). How does the mode of inheritance of a genetic condition influence families? A study of guilt, blame, stigma, and understanding of inheritance and reproductive risks in families with $X$-linked and autosomal recessive diseases. Genetics in Medicine: Official Journal of the American College of Medical Genetics, 8(4), 234-241.

KENNESON, A.; BOBO, J.K. (2010). The effect of caregiving on women in families with Duchenne/Becker muscular dystrophy. Health and Social Care in the Community, 18(5), 520-528.

KOLSDORF, M., COSTA-JUNIOR, A.L. (2008). Estratégias de enfrentamento de pais de crianças em tratamento de câncer. Estudos de Psicologia, 25(3), 417-429.

KOVÁCS, M.J. (2002). Morte e Desenvolvimento Humano. São Paulo, Casa do Psicólogo.

KOVACS, M.J. (2008). Desenvolvimento da Tanatologia: estudos sobre a morte e o morrer.Paidéia (Ribeirão Preto), Ribeirão Preto, v. 18, n. 41, Dec. 2008. Available from <http://www.scielo.br/scielo. php?script $=$ sci_arttext $\&$ pid $=$ S0103-863X2008000300004\&lng $=$ en\&nrm $=$ iso $>$. access on 10 Ago. 2012. http://dx.doi.org/10.1590/S0103-863X2 008000300004 .

KROB, A.D.; PICCININI, C.A.; SILVA, M.R. (2009). A transição para a paternidade: da gestação ao segundo mês de vida do bebê. Psicologia UsP, São Paulo, abril/junho, 20(2),pp. 269-291.

KUBLER-ROSS, E. (1995). Sobre a morte e o morrer. São Paulo: Martins Fontes.

LEMAY, C.A.; CASHMAN, S.B.; ELFENBEIN, D.S.; FELICE, M.E. (2010). A qualitative study of the meaning of fatherhood among young urban fathers. Public Health Nursing, v.27, n.3, p.221-231.

LEVY, J.A. coord. (1989) Doenças musculares: estudo clínico e diagnóstico. 2a reimpressão. São Paulo: Livraria Atheneu. 
LUCCHETTI, G., LUCCHETTI, A.L.G., BADAN-NETO, A.M., PERES, P.T., PERES, M. F. P., MOREIRA-ALMEIDA, A., GOMES, C., KOENIG, H.G. (2011) Religiousness affects mental health, pain and qualit $\mathbf{y}$ of life in older people IN an outpatient rehabilitati on setting. J Rehabil Med; 43: 316-322.

LÜDKE, M; ANDRÉ, M.E.D. (1986). A Pesquisa em educação: abordagens qualitativas. São Paulo: EPU.

MANFROI, E.C., MACARINI, S.M., VIEIRA, M.L. (2011). Comportamento parental e o papel do pai no desenvolvimento infantil. Rev. Bras. Cresc. e Desenv. Hum., 21(1), 59-69.

MENEZES, C.N.B.; PASSARELI, P.M.; DRUDE, F.S.; SANTOS, M.A.; VALLE, E.R.M. (2007). Câncer infantil: organização familiar e doença. Revista Mal-estar e Subjetividade, Revista Mal-estar e Subjetividade, VII (1), Fortaleza, mar/2007, 191-210.

MILLER, A.R.; CONDIN, C.J .; MCKELLIN, W.H.; SHAW, N.; KLASSEN, A.F.; SHEPS, S. (2011). Continuity of care for children with complex chronic health conditions: parents' perspectives. Disponível em < http://www.biomedcentral.com/1472-6963/9/242. Acessado em 21 de Maio de 2011.

MINAYO, M.C.S. (1993). O desafio do conhecimento. Pesquisa qualitativa em saúde. Rio de Janeiro: Hucitec-Abrasco.

MINUCHIM, S. (1990). Famílias funcionamento e tratamento. Trad. De Jurema Alcides Cunha. Porto Alegre: Artes Médicas.

MOREIRA, A.S.S.; ARAÚJO, A.P.Q.C. (2009). Não reconhecimento dos sintomas iniciais na atenção primária e a demora no diagnóstico da Distrofia Muscular de Duchenne. Revista Brasileira de Neurologia, Vol. 45, n. 40, 3 jul - ago - set.

MOREIRA, L.V.C, PETRINI, G., BARBOSA, F.B. (org) (2010) O pai na sociedade comtemporânea. Bauru, SP: Edusc.

MOREIRA-ALMEIDA, A., LOTUFO NETO, F., KOENIG, H.G. (2006). Religiousness and mental health: a review. Revista Brasileira de Psiquiatria, 28(3), 242-250. Epub August 10, 2006. Retrieved February 17, 2012, from http://www.scielo.br/scielo.php?script=sci_arttext\&pid= S1516-44462006000300018\&Ing=en\&tIng=en. 10.1590/S1516-44462006 005000006. 
MUCCHIELLI, R. (1978). O questionário na pesquisa psicossocial, São Paulo: Martins Fontes.

MUCCHIELLI, R. (1994) A entrevista não diretiva. 2.ed. São Paulo: Martins Fontes.

MURATA, M.F., PETEAN, E.B.L. (2000). PARALISIA CEREBRAL: CONHECI MENTO DAS MÃES SOBRE O DIAGNÓSTI CO E O IMPACTO DESTE NA DI NÂMI CA FAMI LI AR1 Paidéia, FFCLRP-USP, 40-46.

NASCIMENTO, C.A.D., MONTEIRO, E.M.L.M., VINHAES, A.B., CAVALCANTI, L.L., RAMOS, M.B. (2009). O câncer infantil (Leucemia): Significações de algumas vivências maternas. Rev. Rene. Fortaleza, 10 (2), 149-157.

NOLASCO, S. (1995) 0 mito da masculinidade. 2a ed. Rio de Janeiro: Editora Rocco.

NUNES, C.C., SILVA, N.C.B.; AIELLO, A.L.R. (2008). As contribuições do papel do pai e do irmão do indivíduo com necessidades especiais na visão sistêmica da família. Psic.: Teor. e Pesq. , Brasília, v. 24, n. 1, 2008. Disponível em: <http://www.scielo.br/scielo.php?script=sci_ arttext\&pid=S0102-37722008000100005\&lng $=\& n r m=i s o>$. Acesso em: 16 2010. doi: 10.1590/S0102-37722008000100005.

PANGALILA, R.F., BOS, G.A.M. van den, STAM, H.J., EXEL, N.J.A. van, BROUWER, W.B.F., ROEBROECK, M.E. (2012). Subjective caregiver burden of parents of adults with Duchenne muscular dystrophy. Disability \& Rehabilitation, June, 34 (12), 988-996.

PANGANIBAN-COLARES, A.T., MEDINA, M.F. (2011). Family resources study: part 1: family resources, family function and caregiver strain in childhood cancer. Asia Pacific Family Medicine, 10:14.

PELISOLI, C.; DELL'AGLIO, D.D. (2008). Do segredo à possibilidade de reparação: um estudo de caso sobre relacionamentos familiares no abuso sexual. Contextos Clínicos, 1(2), 49-60.

PETEAN, E.B.L.(2004). Enfrentando a deficiência: a pesquisa com famílias e profissionais. Tese (Livre-Docência) - Faculdade de Filosofia Ciências e Letras de Ribeirão Preto - Universidade de São Paulo. 
PETEAN, E.B.L., SIGUIHURA, A.L.M. (2005). Ter um irmão especial: convivendo com a síndrome de Down. Rev. Bras. Ed. Esp., Marília, Set.-Dez., 11 (3), 445-460.

POLONIA, A.C.; DESSEN, M.A.; PEREIRA-SILVA, N.L. (2005). O modelo bioecológico de Bronfenbrenner: contribuições para o desenvolvimento humano. In: DESSEN, M.A.; COSTA JUNIOR, A.L. (Org.). A ciência do desenvolvimento humano: tendências atuais e perspectivas futuras. Porto Alegre: Artmed.

PONTES-FERNANDES, A.C., PETEAN, E.B.L. (2011). Sobrecarga Emocional e Qualidade de Vida em Mães de Crianças com Erros I natos do Metabolismo. Psicologia: Teoria e Pesquisa, 27 (4), 459-465.

POVEE, K., ROBERTS, L., BOURKE, J., LEONARD, H. (2012). Family functioning in families with a child with Down syndrome: a mixed methods approach. Journal of Intellectual Disability Research, 56: 961973.

POYSKY, J., KINNETT, K. (2008). Facilitating family adjustment to a diagnosis of Duchenne muscular dystrophy. Neuromuscular Disorders, 19, 733-738.

RANDO, T.A. (2000). Clinical Dimensions of Antecipatory Mourning, Illinois, Research Press.

REGEN, M.; ARDORE, M.; HOFFMANN, V. M. B. (1993). Mães e Filhos Especiais: Relato de experiência com grupos de Mães de crianças com deficiência. BRASÍLIA: Coordenadoria Nacional para Integração da Pessoa Portadora de Deficiência - C O R D E.

$\mathrm{RIBI}, \mathrm{K}$ et al. (2007). Prediction of posttraumatic stress in fathers of children with chronic diseases or unintentional injuries: a sixmonths follow-up study. Child and Adolescent Psychiatry and Mental Health, 1:16.

RIGÃO, T.V.C., RIBEIRO, K.S.Q.S., GERMANO, C.F.M., NEVES, P.M., BRITO, G.E.G. (2011). Networks of social support of the families with disabled children. J ournal of Nursing UFPE on line, Disponível em: http://www.revista. ufpe. br/revistaenfermagem/index.php/revista. Acesso em: 16 mar 2012. 
ROLAND, J.S. (2001) Doença crônica e o ciclo de vida familiar In: CARTER, B.; MCGOLDRICK, M. As mudanças no ciclo de vida familiar: uma estrutura para a terapia familiar. Trad. Maria Adriana Veríssimo Veronese. 2.ed. 2.Reimpressão. Porto Alegre: Artes Médicas.

ROSSET, M.O.S. (2009). A sobrecarga na família de crianças com paralisia cerebral. Dissertação (Mestrado em Ciências - Enfermagem Psiquiátrica) - Escola de Enfermagem de Ribeirão Preto - Universidade de São Paulo, Ribeirão Preto.

SALTER, R.B. (2001). Distúrbios e lesões do sistema musculoesquelético. 3.ed. Rio de Janeiro: Medsi.

SILVA, L.M. (2006). O estranhamento causado pela deficiência: preconceito e experiência. Revista Brasileira de Educação, 11 (33), set./dez, 424-434.

SILVA, M.; PICCININI, C.A. (2007). Sentimentos sobre a paternidade e o envolvimento paterno: um estudo qualitativo. Estudos de Psicologia, Campinas, 24(4), 561-573, outubro - dezembro.

SILVA, N.L.P; DESSEN, M.A. (2003). Crianças com Síndrome de Down e suas interações familiares. Psicologia , Reflexão e Crítica, 16(3), pp. 503-514.

SOUZA, C.L.C.; BENETTI, S.P.C. (2008). Paternidade e desemprego: características do envolvimento paterno e aspectos do relacionamento familiar. Contextos Clínicos, v.1, n.2, p.61-71.

SOUZA, J. (2008). Filhos de alcoolistas: afetividade e conflito nas relações familiares. Tese (Doutorado) - Escola de Enfermagem de Ribeirão Preto - Universidade de São Paulo.

STAUDT, A.C.P.; WAGNES, A. (2008). Paternidade em tempos de mudança. Psicologia: Teoria e Prática, 10(1): pp174-185.

TEYKAL, C.M. (2007). De pai para filho: uma reflexão sobre identidade paterna e transmissão intergeracional em duas diferentes gerações. Dissertação (Mestrado em Psicossociologia de Comunidades e Ecologia Social) - Universidade Federal do Rio de Janeiro, Instituto de Psicologia. 
WATTS, R.J . (2010). Advancing a community psychology of men. Am J Community Psychol, v.45, p.201-211.

WORTMANN, J.H., Park, C.L. (2009). Religion/ Spirituality and Change in Meaning after Bereavement: Qualitative Evidence for the Meaning Making Model, Journal of Loss and Trauma: International Perspectives on Stress \& Coping, 14:1, 17-34.

ZACHI, E.C., TAUB, A., VENTURA, D.F. (2012) Perfil comportamental e competência social de crianças e adolescentes com distrofia muscular de Duchenne. Estudos de Psicologia, 17(1), janeiro-abril, 179186. 
ANEXOS 



\section{ANEXO A}

\section{Procedimento de Reavaliação do roteiro semi-estruturado da entrevista e as modificações efetuadas.}

Depois de transcritas as entrevistas realizadas no pré-teste, alguns itens necessitaram ser acrescentados, excluídos e outros modificados. De modo geral, os itens que foram excluídos não estavam contribuindo para esclarecer os objetivos do projeto. Quase a totalidade dos itens alterados, o foram para adequação da linguagem.

Para tanto considerou-se as respostas dadas pelos dois pais entrevistados na fase de pré-teste e as reformulações feitas pela entrevistadora durante as entrevistas de pré-teste.

O tópico V: Mudanças percebidas nas interações após 0 diagnóstico não precisou sofrer alterações.

\section{Tópico I: I dentificação familiar}

Foi incluído o item 0 casal tem outros filhos, antes da questão Ordem de nascimento dos filhos, para obter a informação se a família tem outros filhos e só questionar a ordem de nascimento em caso afirmativo.

O item:

Data de nascimento foi alterado para I dade, pois não haverá necessidade de se calcular a idade posteriormente e para facilitar recordação, especialmente quando se questiona informações sobre a esposa.

O item:

Sabe qual é o diagnóstico do filho foi alterado para Sabe qual é o diagnóstico de nome da pessoa com DMD), objetivando tornar a pergunta mais clara, quando há mais de um filho com o mesmo diagnóstico. 
O item:

Outros residem na mesma casa foi substituído por

Quem reside na mesma casa, para facilitar a compreensão.

O item:

Qual a renda familiar (em salários mínimos) e como é composta foi alterado para Renda familiar (em salários mínimos), simplificando a informação já que a composição da renda familiar não seria relevante aos objetivos deste trabalho. A ordem dos itens foi alterada com o objetivo de facilitar o fluxo de informações.

\section{Tópico II : Dados sobre a gestação}

$O$ item houve algum tipo de problema durante a gravidez foi excluído, pois não se obteve as informações desejadas com este questionamento.

Foi incluído o item $\mathbf{O}$ que você pensava sobre ser pai antes de saber que teria um filho, com a finalidade de obter informações acerca da percepção da paternidade antes da notícia da gravidez.

$O$ item:

A gravidez foi planejada foi alterado para A gravidez de (nome da pessoa com DMD) foi planejada, para especificar a gravidez do filho com DMD sobre o qual o trabalho está sendo realizado.

O item:

Como foi a gravidez foi alterado para Como foi a gravidez de (nome da pessoa com DMD), com a mesma justificativa do item anterior.

A ordem dos itens foi alterada com o objetivo de facilitar o fluxo de informações.

Tópico III : Dados sobre o diagnóstico

Foram incluídos os itens Quando o senhor soube que (nome da pessoa com DMD) estava doente e $O$ que o senhor imaginava para o futuro do seu filho antes do diagnóstico. 
Foram excluídos os itens Quais as condições da sua vida e da família antes do diagnóstico (relacionamentos, projetos para o futuro) e Há quanto tempo o diagnóstico aconteceu.

O item:

Quando o senhor (ou a mãe) percebeu que seu filho estava doente foi alterado para Quem percebeu que (nome da pessoa com DMD) estava com problema.

O item:

Como se deu o diagnóstico foi alterado para Como foi feito o diagnóstico de DMD.

O item:

Qual foi sua reação quando soube da doença do seu filho foi alterado para Qual foi sua reação quando soube da doença de ( nome da pessoa com DMD).

O item:

Quais foram seus sentimentos na época do diagnóstico foi alterado para Como se sentiu naquela época.

Tópico IV: Mudanças inseridas pela doença na rotina diária e de cuidados com o filho

Foi incluído o item Quem realiza os cuidados com (nome da pessoa com DMD).

Foram excluídos os itens Como a família se organiza quando há necessidade de levar o filho para os atendimentos específicos (médico, fisioterapia, hidroterapia); As internações ocorrem frequentemente; Como a família se organiza quando o filho precisa de internação e Quais são as atividades que a família consegue realizar conjuntamente.

Os itens: Seu filho precisa de cuidados especiais hoje em dia e Quais são estes cuidados foram alterados para Quais os cuidados que o filho requer hoje em dia? Quais são estes cuidados?

O item: 
Seu filho dorme com alguém foi alterado para (nome da pessoa com DMD) dorme com alguém? Onde?

Tópico VI : Percepção sobre a paternidade

O item:

1.1. Como você percebe sua contribuição na adaptação da família à doença foi alterado para Como você que contribui na adaptação da família à doença. 
ANEXO B

\section{Roteiro Final da Entrevista}

Data da entrevista: I

\section{I dentificação Familiar:}

Nome (Pai):

Idade: ___ Escolaridade: _____-_ Ocupação:

Nome da Esposa:

Idade: ___ Escolaridade:_____-_ Ocupação:

Renda familiar (em salários mínimos)

Ordem de nascimento do(s) filho(s)

Quem reside na mesma casa:

Sabe qual é o diagnóstico de $?$

Há outro filho com o mesmo diagnóstico? 


\section{Dados sobre a Gestação:}

2.1. O que você pensava sobre ser pai antes de saber que teria um filho?

2.2. A gravidez de foi planejada?

2.3. Como você se sentiu quando soube que iria ser pai?

2.4. Como foi a gravidez de $?$

2.5. Quais eram suas expectativas com relação a seu filho na época da gravidez?

2.6. Durante o período da gravidez, o que o senhor considerava que seria o papel do pai?

\section{Dados sobre o diagnóstico}

3.1. Quando o senhor soube que estava doente?

3.2. Quem percebeu que estava com problema?

3.3. Como foi feito o diagnóstico de DMD?

3.4. Quais as informações que você recebeu a respeito da DMD na época do diagnóstico?

3.5. Qual foi sua reação quando soube da doença de $?$

3.6. Como se sentiu naquela época?

3.7. O que o senhor imaginava para o futuro do seu filho antes do diagnóstico?

3.8. Em sua opinião, qual o motivo pelo qual ele tem DMD? 
3.9. O que você sabe sobre a DMD hoje?

\section{Mudanças inseridas pela doença na rotina diária e de cuidados com o filho}

4.1. Quais os cuidados que o filho requer hoje em dia? Quais são estes cuidados?

4.2. Quem realiza os cuidados com $?$

4.3. Você ajuda nos cuidados diários de $?$

4.4. Como se sente ao fazê-lo?

4.5. Alguém mais ajuda nos cuidados de seu filho? Quem?

4.6. dorme com alguém? Onde?

4.7. Atualmente quais são suas atividades junto ao seu filho?

4.8. Existem momentos em que a família pode fazer programas juntos?

\section{Mudanças percebidas nas interações após o diagnóstico}

5.1. Em sua opinião, houve mudanças na vida familiar depois do diagnóstico? (se sim, quais?)

5.2. Em sua opinião, houve alguma mudança na relação com sua esposa? (se sim, quais?)

5.3. Em relação às outras pessoas da família e das suas amizades, o senhor percebe que houve alguma mudança no relacionamento? (se sim, quais?) 


\section{Percepção sobre a paternidade}

6.1. Que tipo de atividades você e seu filho faziam juntos antes da doença?

6.2. Como você que contribui na adaptação da família à doença?

6.3. O que você considera que são funções de um pai hoje?

6.4. Como tem sido ser pai de uma criança com DMD?

6.5. Quais as suas expectativas em relação ao seu filho?

6.6. Quais as suas expectativas para o seu futuro e da família?

6.7. Que tipo de pai você gostaria de ser para o seu filho?

\section{Percepção sobre si mesmo}

7.1. Fale sobre como você se sente em relação à sua vida atualmente. 


\section{ANEXO C \\ Termo de Consentimento Livre e Esclarecido}

Meu nome é Silvana Aparecida De Lucca, psicóloga e aluna do programa de pós-graduação em Psicologia da Faculdade de Filosofia, Ciências e Letras de Ribeirão Preto, Universidade do Estado de São Paulo e pretendo realizar uma pesquisa sobre as interações familiares na presença de um membro com diagnóstico de Distrofia Muscular de Duchenne (DMD). Mais especificamente este trabalho pretende investigar como o pai de um portador de DMD se percebe nas relações familiares (pai/filho e marido/mulher) e como isto influencia nestas interações e na função paterna. Pretende-se com os conhecimentos oriundos com este trabalho, obter informações relevantes para se ajudar à família como um todo e seus membros a uma melhor adaptação psicológica.

Para tanto, gostaria de contar com a sua colaboração neste estudo e decidindo-se a participar, pedirei que responda a um questionário e uma entrevista com perguntas sobre o tema descrito anteriormente. Esta entrevista será gravada na integra para transcrição posterior. Sobre estas informações, explico que o sigilo e o anonimato são garantidos.

Esclareço ainda que a participação não implica em riscos de qualquer espécie para o participante e seus familiares e que também não gera custos, já que o participante poderá optar por realizar a entrevista em sua residência ou em outro local acordado entre o participante e a pesquisadora.

Caso queiram entrar em contato com a pesquisadora responsável, ou solicitar qualquer esclarecimento, utilizem o telefone 3234.3291 ou o endereço de correspondência: Rua Niterói, 135 apto 43C - Ribeirão Preto - SP - CEP: 14090-710. 
SILVANA APARECIDA DE

LUCCA

Pesquisadora
Prof. Dr. a EUCIA BEATRIZ L. PETEAN

Orientadora

Em concordância com o exposto acima, eu,

porrtador do RG

aceito participar

desta pesquisa, sendo minha participação voluntária e livre para desistir a qualquer momento, sem nenhum prejuízo à minha pessoa e meus familiares. Outrossim, declaro estar ciente de que os dados e resultados obtidos poderão ser utilizados em pesquisa acadêmica resguardando o sigilo, sob a responsabilidade da pesquisadora. Declaro ainda ter recebido uma copia legível deste termo e a possibilidade de poder lê-lo.

Assinatura

Ribeirão Preto, de de 